\title{
Characterization of the genetic architecture of BMI in infancy and early childhood reveals age-specific effects and implicates pathways involved in Mendelian obesity
}

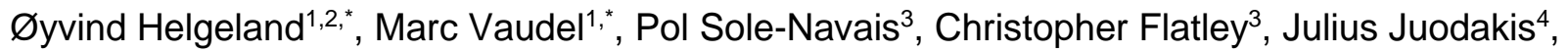
Jonas Bacelis ${ }^{4}$, Ingvild L. Koløen ${ }^{1,5}$, Gun Peggy Knudsen ${ }^{6}$, Bente B. Johansson ${ }^{1}$, Per Magnus ${ }^{7}$, Ted Reichborn Kjennerud ${ }^{8,9}$, Petur B. Juliusson ${ }^{10,11}$, Camilla Stoltenberg ${ }^{6}$, Oddgeir L. Holmen ${ }^{12}$, Ole A. Andreassen ${ }^{13,14}$, Bo Jacobsson ${ }^{2,3}$, Pål R. Njølstad ${ }^{1,15, \square}$, Stefan Johansson ${ }^{1,5, \square}$

\section{*shared first authors}

${ }^{1}$ Center for Diabetes Research, Department of Clinical Science, University of Bergen, NO-5020 Bergen, Norway.

${ }^{2}$ Department of Genetics and Bioinformatics, Health Data and Digitalization, Norwegian Institute of Public Health, NO-0473 Oslo, Norway.

${ }^{3}$ Department of Obstetrics and Gynecology, Institute of Clinical Sciences, Sahlgrenska Academy, University of Gothenburg, SE-41685 Gothenburg, Sweden.

${ }^{4}$ Department of Gynecology and Obstetrics, Sahlgrenska Academy, University of Gothenburg, SE-40530 Gothenburg, Sweden.

${ }^{5}$ Department of Medical Genetics, Haukeland University Hospital, NO-5020 Bergen, Norway.

${ }^{6}$ Norwegian Institute of Public Health, NO-0473 Oslo, Norway.

${ }^{7}$ Centre for Fertility and Health, Norwegian Institute of Public Health, NO-0473 Oslo, Norway.

${ }^{8}$ Department of Mental Disorders, Norwegian Institute of Public Health, NO-0473 Oslo, Norway.

Institute of Clinical Medicine, University of Oslo, NO-0315 Oslo, Norway.

${ }^{10}$ Department of Health Registry Research and Development, National Institute of Public Health, NO-5015

Bergen, Norway.

${ }^{11}$ Department of Clinical Science, University of Bergen, NO-5020 Bergen, Norway.

${ }^{12}$ HUNT Research Centre, Department of Public Health and Nursing, Faculty of Medicine and Health

Sciences, Norwegian University of Science and Technology, NO-7491 Trondheim, Norway.

${ }^{13}$ NORMENT Centre, Institute of Clinical Medicine, University of Oslo, NO-0315 Oslo, Norway.

${ }^{14}$ Division of Mental Health and Addiction, Oslo University Hospital, NO-0315 Oslo, Norway.

${ }^{15} \mathrm{Children}$ and Youth Clinic, Haukeland University Hospital, NO-5020 Bergen, Norway.

\section{Correspondence:}

Professor Stefan Johansson, Ph.D., Center for Diabetes Research, Department of Clinical Science, University of Bergen, NO-5020 Bergen, Norway (stefan.johansson@uib.no)

Professor Pål Rasmus Njølstad, M.D., Ph.D., Center for Diabetes Research, Department of Clinical Science, University of Bergen, NO-5020 Bergen, Norway (pal.njolstad@uib.no) 
medRxiv preprint doi: https://doi.org/10.1101/2021.05.04.21256508; this version posted May 7, 2021. The copyright holder for this preprint (which was not certified by peer review) is the author/funder, who has granted medRxiv a license to display the preprint in perpetuity.

\section{Abstract}

To elucidate the role of common genetic variation on infant and child weight development, we performed genome-wide association studies across 12 time points from birth to eight years in 28,681 children and their parents (27,088 mothers and 26,239 fathers) in the Norwegian Mother, Father and Child Cohort Study (MoBa). We identify 46 distinct loci associated with early childhood BMI at specific ages, matching different child growth phases, and representing four major trajectory patterns. Among these loci, 30 are independent of known birth weight and adult BMI loci, and 21 show peak effect between six months and three years, making these discoverable only at early age. Several of the 21 variants reside in/near genes previously implicated in severe forms of early-onset obesity, and monogenic obesity genes are enriched in the vicinity of the 46 loci. Four loci demonstrate evidence of several independent association signals as key drivers for BMI development near LEPR, GLP1R, PCSK1, and KLF14, all central to appetite and energy balance. At the KLF14 locus, we detect significant associations for maternally inherited alleles only, consistent with imprinting effects. Finally, we demonstrate how the BMI distribution stratified by different polygenic risk scores transitions from birth to adult profile throughout early childhood, and how age-specific polygenic risk scores improve the prediction of childhood obesity, outperforming scores based on adult BMI. In conclusion, our results offer a fine-grained characterization of the rapidly changing genetic association landscape sustaining early growth. 
medRxiv preprint doi: https://doi.org/10.1101/2021.05.04.21256508; this version posted May 7, 2021. The copyright holder for this preprint (which was not certified by peer review) is the author/funder, who has granted medRxiv a license to display the preprint in perpetuity.

\section{Main}

Physical growth is an indicator and predictor of both present and future health. Deviations from a child's growth trajectory may indicate health issues with life-long implications. Growth in infancy and early childhood is thus monitored closely by parents and health care professionals. Early increase in body mass index (BMI) is notably associated with diabetes, earlier puberty, risk of obesity in adolescence and adulthood, a major public health issue worldwide ${ }^{12,3}$, and the many complications that follow. Only $38 \%$ of adults with class II/II obesity (BMI $\left.\geq 35 \mathrm{~kg} / \mathrm{m}^{2}\right)$ present normal weight during childhood ${ }^{4}$, and $90 \%$ of all children defined as obese at age three remain obese during adolescence ${ }^{5}$. As sustainable weight reduction has proved difficult ${ }^{6}$, proactive therapeutic strategies enabling early prevention of obesity are sorely needed, and this can only be achieved through a better understanding of the fundamental mechanisms regulating early growth.

Heritability estimates for $\mathrm{BMI}$ in twin studies range from 40 to $70 \%$ and vary with age $\mathrm{e}^{7,8}$. Genetic variants strongly influence the risk of obesity, in a complex relationship with behavioural and lifestyle factors ${ }^{9}$. Common genetic variants explain 17 to $27 \%$ of the heritability of $\mathrm{BMI}^{10-12}$. The genetics of early weight development is therefore of prime scientific interest for children's health, but also as a predictor for adult obesity. The largest genome-wide association study (GWAS) on adult BMI has identified 941 independent loci in over 700,000 individuals, explaining $\sim 6 \%$ of the phenotypic variation ${ }^{13}$. In children, where sample sizes are much smaller, less is known about the genetics of BMI. Recent meta-analyses suggest a substantial overlap with adult BMI ${ }^{14-16}$, while studies estimating age-dependent genetic contribution have revealed low correlation in infancy and early childhood that gradually increases with age ${ }^{10}$. Additionally, transient genetic association with early BMI during infancy and early childhood has been identified by us and others $^{17,18}$, suggestive of rapid changes in the genetic architecture of BMI during early growth. 
medRxiv preprint doi: https://doi.org/10.1101/2021.05.04.21256508; this version posted May 7, 2021. The copyright holder for this preprint (which was not certified by peer review) is the author/funder, who has granted medRxiv a license to display the preprint in perpetuity.

It is made available under a CC-BY 4.0 International license .

But how the genetics of BMI develops from birth to adiposity rebound, where the genetic signature of an adult-like obesity emerges, remains unknown.

Studies among children with severe obesity have identified rare genetic variants that cause early-onset monogenic and syndromic forms of obesity ${ }^{19,20}$. A recent investigation of severe childhood obesity found an excess burden of rare, predicted deleterious, variants involving genes near adult obesity loci ${ }^{21}$. Variants with different penetrance were detected in genes in the leptin/melanocortin pathway, a major determinant of satiety and energy expenditure. Interestingly, GWASs suggest that the LEP-LEPR axis is also central to BMI development during infancy and childhood ${ }^{17,18}$.

In this study, we investigated the association of common variation with BMI from birth to eight years of age through a longitudinal analysis in the Norwegian Mother, Father and Child Cohort Study $(\mathrm{MoBa})^{22}$. Using this unique pregnancy-based open-ended cohort with dense harmonized phenotypes and genotypes from both parents and child, we here present a detailed characterization of the rapidly changing genetic landscape of BMI during the first years of life.

\section{Results}

BMI from 28,681 children was measured at birth, 6 weeks, 3, 6, 8 months, and 1, 1.5, 2, 3, 5, 7, and 8 years of age (Supplementary Table 1). At each time point we conducted linear mixed model regression analyses on standardized BMI under an additive genetic model, followed by approximate conditional and joint multiple single-nucleotide polymorphism (SNP) analyses to identify independent signals ${ }^{23}$, resulting in 46 independent loci reaching genome-wide significance $\left(p<5 \times 10^{-8}\right)$ for at least one time point (Table 1). Of these, 30 are independent of the birth weight and adult BMI loci reported in the latest meta-analyses ${ }^{13,24}$. 
medRxiv preprint doi: https://doi.org/10.1101/2021.05.04.21256508; this version posted May 7, 2021. The copyright holder for this preprint (which was not certified by peer review) is the author/funder, who has granted medRxiv a license to display the preprint in perpetuity.

It is made available under a CC-BY 4.0 International license .

\section{Four major association trajectory clusters emerge}

We investigated the dynamics of the association for the 46 loci by projecting their effect sizes over time onto a basis of reference profiles (Figure 1). The variants displayed different trajectories (Figure 1C), demonstrating how the genetics of early childhood BMI is an agedependent combination of interweaved signals. Four major clusters of profiles emerged (Figure 1E), which we hypothesize to represent distinct biological processes.

The Birth cluster represents nine loci previously associated with birth weight ${ }^{24}$. Our longitudinal analysis showed that the association near SH2B3, CCNL1, GPSM1, GCK, and DLG4 quickly vanishes after birth, indicating that these loci are conferring pure prenatal influences, while loci near ESR1, DLK1, and HHEX seem to influence growth also postnatally (Figure 1 and Figure 2). The trajectory of $A D C Y 5$, known primarily as a type 2 diabetes (T2D) locus, is remarkable in presenting a strong association at birth which rapidly disappears, followed by a steady increase during infancy and childhood, but almost no association with adult BMI ${ }^{13}$ (Figure 1 and Figure 2).

The Transient cluster represents 21 independent signals with no effect at birth, peak association during infancy or early childhood, and little or no effect after the adiposity rebound. None of the SNPs in this cluster reach genome-wide significance $\left(p<5 \times 10^{-8}\right)$ in the largest adult BMI meta-analysis to date ${ }^{13}$ (Figure 1 and Figure 2), and among SNPs that reach $\mathrm{p}<1 \times 10^{-5}$, three out of four have opposite direction of effect on BMI in adults compared to infancy (LEPR(rs10493377), MLXIPL(rs17145750) and KLF14(rs287621)). Conversely, of the variants previously implicated in birth weight, only one ( $P T C H 1(\mathrm{rs} 28457693))$ is present in this cluster. Thus, this cluster represents biological mechanisms with distinct effects on BMI development in infancy and childhood. The other phenotypes associated with the loci in this 
medRxiv preprint doi: https://doi.org/10.1101/2021.05.04.21256508; this version posted May 7, 2021. The copyright holder for this preprint (which was not certified by peer review) is the author/funder, who has granted medRxiv a license to display the preprint in perpetuity.

It is made available under a CC-BY 4.0 International license .

cluster are primarily anthropometric traits (Figure 1 ), yet the majority (11 of 21 ) are not known to be associated with adult traits.

The Early Rise cluster represents 12 loci showing a gradually stronger association with BMI from infancy into childhood. In contrast with the variants from the Transient cluster, the association levels plateau around adiposity rebound and maintain some effect until age seven to eight years. This cluster includes variants associated with self-estimated comparative height and size at age ten years in the UK Biobank, as well as traits related to adult body composition, which supports the hypothesis of a more persisting effect. However, only two SNPs in this cluster (ADCY3(rs11676272) and TNNI3K(rs10493544)) reach genome-wide significance in the largest adult BMI study ${ }^{13}$, and one (AC105393.2(rs77165542)) with no proxy in Yengo et al ${ }^{13}$ showed an association with BMI in the parents in $\mathrm{MoBa}$, the nine others show no association with adult BMI per se (Figure 1 and Figure 2).

The Late Rise cluster, represents four loci (FTO(rs17817288), MC4R(rs78263856), SEC16B(rs545608), and FAIM2(rs7132908)) that show little to no association prior to adiposity rebound where they exhibit a rapid increase contrasting with the other clusters. The variants in the Late Rise cluster are in high LD with loci reported in a previous study on childhood BMI consisting mainly of children measured at age six to ten years ${ }^{14}$ and with adult BMI ${ }^{13}$ (Figure 2). The observed upward trajectory therefore yields effects that seem to remain significant into adulthood.

\section{Distribution of previously detected birth weight and adult BMI SNPs}

Figure $1 \mathrm{H}$ shows the density of the overall distribution of trajectory profiles in MoBa for all previously detected birth weight and adult BMI SNPs ${ }^{13,24}$ along with the density of the 46 early growth loci detected in this study: the trajectories for birth weight and adult BMI segregate to the left and right sides of the space defined by the reference profiles, respectively, while the early 
medRxiv preprint doi: https://doi.org/10.1101/2021.05.04.21256508; this version posted May 7, 2021. The copyright holder for this preprint (which was not certified by peer review) is the author/funder, who has granted medRxiv a license to display the preprint in perpetuity.

It is made available under a CC-BY 4.0 International license .

growth BMI is dominated by transient profiles. In contrast to the association profiles in our Birth cluster, the birth weight variants mostly display trajectories persisting or rising throughout childhood. Conversely, variants associated with adult BMI present a strong concentration of late rising profiles, suggesting that better power at late ages would provide a higher number of variants in this cluster.

\section{SNP heritability and genetic correlation}

We estimated SNP-based heritability and genetic correlation between various traits and BMI at all time points using LD score regression. The heritability estimates vary with age in a pattern mirroring childhood BMI curves (Supplementary Figure 1). Overall, the phenotypes assessed display age-dependent genetic correlation patterns with BMI, with lower correlation from six months to three years (Figure 3). Birth weight adjusted for maternal effect presents a high correlation with BMI at birth $\left(r_{g}: 0.89\right.$, se: $\left.0.061, p<1 \times 10^{-47}\right)$ that decreases quickly in infancy and throughout childhood, whereas for indirect maternal effects, the correlation is initially lower but increases from one year onwards. While obesity-related traits in general show constant correlation levels before accelerating at three years, comparative body size at age 10 in the UK Biobank, in which participants reported being thinner or plumper than average at age ten years, presents a rapid linear increase throughout development from birth to seven years $\left(r_{g}: 0.86\right.$, se: $0.06, p<9 \times 10^{-53}$, which is in line with the observed overlap of this phenotype with the Early and Late Rise clusters. Higher childhood BMI correlates with younger age of menarche, taller stature in early puberty but not during adulthood, indicating a strong genetic correlation between childhood BMI and early pubertal development. The well-known inverse relationship of T2D with fetal growth vanishes quickly after birth and the genetic correlation of BMI with glycaemic traits varies rapidly throughout childhood, suggesting a continuous interplay between genetic variation influencing insulin metabolism and growth. 
medRxiv preprint doi: https://doi.org/10.1101/2021.05.04.21256508; this version posted May 7, 2021. The copyright holder for this preprint (which was not certified by peer review) is the author/funder, who has granted medRxiv a license to display the preprint in perpetuity.

It is made available under a CC-BY 4.0 International license.

\section{Monogenic obesity and the importance of the leptin/melanocortin pathway}

We further investigated the relationship between our results and childhood obesity by evaluating whether genes involved in monogenic obesity are overrepresented in the vicinity of the loci. Seven out of 42 genes used in routine testing for monogenic and severe early onset obesity reside within $250 \mathrm{~kb}$ of one of the 46 top hits (overrepresentation $p<1.01 \times 10^{-7}$ ). Six of these seven genes encode proteins participating in the leptin/melanocortin pathway (LEP, LEPR (3 variants), PCSK1 (two variants), POMC, $A D C Y 3$, and $M C 4 R$ ) providing compelling support for the importance of this pathway also in normal growth (Supplementary Table 2). The remaining gene, INPP5E, is implicated in MORM Syndrome (OMIM \#610156), a ciliopathy presenting early-onset central obesity ${ }^{25,26}$. Apart from $M C 4 R$, the associated variants belong to the Transient and Early Rise clusters, showing that mechanisms at play act very early after birth, some of which in a narrow age window.

\section{Key roles for variants in the LEP and LEPR loci}

The strongest association with BMI across all time points is the intronic variant rs2767486 with peak association at six months in the LEPR locus (Transient cluster, eaf: 16\%, $\beta$ : 0.14, se: $0.012, p<6.4 \times 10^{-34}$ ), presenting a transient association profile that peaks at six months, in agreement with ${ }^{17,18}$. We also identified two novel independent signals in this locus: the intronic rs 10889551 and rs10493377, located $85 \mathrm{~kb}$ and $112 \mathrm{~kb}$ downstream of rs2767486, respectively. Conditional and joint multiple-SNP analysis and different timings of association confirmed the independence of the three signals (Supplementary Table 3)(Figure 4). The previously described association with rs10487505 in $L E P^{17}$ showed a later and broader association profile, which resulted in its assignment to the Early Rise cluster. Its child BMI-increasing allele is associated with lower plasma leptin levels adjusted for BMI in adults ${ }^{27}$, and our results suggest that the association with BMI is specific to childhood. 


\section{Established BMI variants near ADCY3 and MC4R with lasting effects on BMI}

Both $A D C Y 3$ and $M C 4 R$ are implicated in Mendelian forms of obesity and polygenic BMI in adults and children and expressed in the hypothalamus where they are important for central regulation of energy homeostasis ${ }^{13,28-30}$. The well-known non-synonymous variant $r s 11676272$ in $A D C Y 3$ was the second strongest locus overall for infant and childhood BMI, peaking at one year (Early Rise cluster, eaf: $49 \%, \beta$ : 0.089, se: $0.0093, p<2.8 \times 10^{-22}$ ). The variant rs78263856 upstream of MC4R belongs to the Late Rise cluster with effects on BMI appearing from two years of age, with peak at seven years (Late Rise cluster, eaf: $95 \%, \beta: 0.15$, se: 0.027 , $\mathrm{p}<3.8 \times 10^{-8}$ ), and lasting into adult life (Figure 2).

\section{Novel variants near PCSK1}

We identified two independent loci near the monogenic obesity gene PCSK $1^{31,32}$ (Figure 4). The strongest association was found for rs6899303, downstream of PCSK1 with peak association at six months (Transient cluster, $\beta$ : 0.057, se: $0.0090, p<5.3 \times 10^{-11}$ ). PCSK1 encodes the prohormone convertase 1/3 (PC1/3), highly expressed in the hypothalamic arcuate nucleus regulating food intake and body weight ${ }^{33}$. No previous phenotypic associations are reported for rs6899303, but the variant is a strong $\mathrm{PQTL}$ for $\mathrm{PC} 1 / 3^{34}$. The second signal, tagged by rs263377, displays its strongest association at one year and resides between PCSK1 and CAST (Transient cluster, $\beta: 0.054$, se: $0.0095, p<2.9 \times 10^{-8}$ ). rs263377 associates with multiple adult anthropometric traits including fat-free body mass in the UK Biobank $\left(p<1.84 \times 10^{-9}\right)$. None of the two variants are in LD with the PCSK1 missense variant rs6235 associated with insulin and adult BMI-related traits ${ }^{35}$. The hypothalamic PC1/3 expression is high in two leptin-sensitive neuronal populations: proopiomelanocortin (POMC)-expressing neurons, and neuropeptide $Y$ (NPY) and agouti-related peptide (AgRP)-expressing neurons. In the periphery, PC1/3 is highly 
medRxiv preprint doi: https://doi.org/10.1101/2021.05.04.21256508; this version posted May 7, 2021. The copyright holder for this preprint (which was not certified by peer review) is the author/funder, who has granted medRxiv a license to display the preprint in perpetuity. It is made available under a CC-BY 4.0 International license .

expressed in specific ghrelin-expressing endocrine cells in the stomach, the $\alpha$ - and $\beta$-cells of the islets of Langerhans in the pancreas, and various intestine enteroendocrine cells. These play an important role in appetite, glucose homeostasis, and nutrient assimilation by secreting several PC1/3 products including ghrelin, insulin, and proglucagon-derived peptides such as the hormone glucagon-like peptide-1 (GLP-1).

\section{Three novel variants in GLP1R with different timing and effect on infant BMI}

GLP-1 is released in the small intestines in response to food intake. It interacts with GLP1R abundant in hypothalamic regions regulating feeding behavior ${ }^{36}$, hereby inducing satiety. It is an incretin with insulinotropic effects in response to oral food intake. GLP-1 induces insulin secretion by interacting with beta cell GLP1R. We identified three independent signals at the GLP1R locus belonging to the Transient cluster (Figure 4): (1) an LD region spanning the promoter and first exon of GLP1R with peak association at three months with lead SNP rs2268657; (2) one intergenic LD block spanning the gene itself with lead SNP rs2268647, peaking at one year; and (3) a $20 \mathrm{~kb}$ region with lead SNP rs1820721, $45 \mathrm{~kb}$ downstream GLP1R, between the SAYSD1 and KCNK5 genes, with peak association at six months. Conditional and joint analysis revealed a complex relationship and timing between the signals. The strength of association increased for all three variants when analysed together, and in particular for rs1820721 (at six months $\mathrm{p}_{\text {cojo }}<5.3 \times 10^{-21}$ ), suggestive of allelic heterogeneity at this locus. None of the three SNPs have been associated with childhood or adult BMI. However, the BMI-increasing alleles at rs2268657 and rs2268647 are both associated with lower GLP1R expression in stomach, pancreas, and adipose tissues (GTEx). Interestingly, rs2268657 has previously been associated with gastric emptying rate ${ }^{37}$, where individuals homozygous for the BMI-increasing allele expressed faster gastric emptying rates, suggesting that $G L P 1 R$ variants may affect childhood BMI through higher digestion rate, in line with its function in the treatment of T2D. 
medRxiv preprint doi: https://doi.org/10.1101/2021.05.04.21256508; this version posted May 7, 2021. The copyright holder for this preprint (which was not certified by peer review) is the author/funder, who has granted medRxiv a license to display the preprint in perpetuity.

It is made available under a CC-BY 4.0 International license .

\section{Rapidly decreasing maternal influences at birth for SH2B3, HHEX, and ADCY5}

For each of the 46 independent loci, we extended the association model using the parental genotypes, and conducted child-mother-father trio- and haplotype-resolved analyses. For most loci, the child effect at peak remains after conditioning on the maternal and paternal genotypes, with no noticeable parental effect (Figure 5). However, for five variants, different patterns emerged: three loci from the Birth cluster SH2B3 (rs7310615), HHEX (rs11187129), and $A D C Y 5$ (rs11708067), and two from the Transient cluster near KLF14 (rs287621 and rs12672489).

For the ADCY5 and HHEX loci, associated with T2D and birth weight, the trio analysis demonstrated opposing fetal and maternal effects, as already observed for birth weight ${ }^{24}$, and no effect from the father (Supplementary Table 4). This differs from the SH3B2 locus, where the trio analysis indicated a dual and directionally consistent effect from both maternal and fetal alleles on birth BMI. The association trajectory of these three birth weight loci illustrates how the maternal genome provides heterogeneous indirect effects on fetal growth that vanish after birth with different dynamics (Figure 5 and Supplementary Table 4).

\section{Age-dependent imprinting patterns near KLF14}

We identified two variants associated with childhood BMI upstream KLF14. rs287621 shows peak association at six months (Transient cluster, $\beta$ : 0.064 , se: $0.010, p<3.7 \times 10^{-10}$ ) before sharply declining to a plateau from one to five years and then vanishing (Figure 1 and Figure 2). Separated by an upstream recombination hotspot, rs12672489 displays a different association pattern, assigned to the Early Rise cluster, which does not persist into adulthood (Figure 1 and Figure 2). Maternal imprinting has been demonstrated for $K L F 14$ in $\mathrm{T}^{2} \mathrm{D}^{38}$, with risk alleles associated with increased fasting insulin, reduced high-density lipoprotein (HDL)-cholesterol, and decreased expression in adipocyte in adults, only when inherited from mothers ${ }^{38,39}$. Our 
medRxiv preprint doi: https://doi.org/10.1101/2021.05.04.21256508; this version posted May 7, 2021. The copyright holder for this preprint (which was not certified by peer review) is the author/funder, who has granted medRxiv a license to display the preprint in perpetuity.

It is made available under a CC-BY 4.0 International license.

haplotype analysis revealed that the association for both variants is driven by the maternally inherited allele throughout infancy, with little to no contribution from the paternal alleles and the maternal non-transmitted alleles (Figure 5, Supplementary Table 4), consistent with imprinting effects. While rs287621 is associated with several adult phenotypes, the strongest known association for rs12672489 is comparative body size at age 10 in the UK Biobank $\left(p<3.5 \times 10^{-}\right.$ ${ }^{7}$ ), showing that this variant influences childhood growth despite residing outside of the region critical for adult traits. eQTL studies have linked variants to the abundance of KLF14 transcript in adipose tissue ${ }^{40}$ and a variant near $K L F 14$ has been associated with lower plasma leptin levels ${ }^{41}$, offering a mechanistic hypothesis and yet another putative link between leptin regulation and weight gain in infancy.

\section{Polygenic transition across infancy and childhood}

Individual-level polygenic risk scores (PRS) were created using PRSice- $2^{42}$ for each time point using summary statistics from the largest meta-analyses on birth weight ${ }^{24}$, childhood $\mathrm{BMI}^{14}$, childhood obesity ${ }^{16}$, adult $\mathrm{BMI}^{13}$, and $\mathrm{T}^{2} \mathrm{D}^{43}$. We then stratified the study population by PRS decile for each of the traits across all time points to investigate their relationship with BMI over time. Strong age-dependent gradients were found with opposing patterns for birth weight and BMI-related traits (Figure 6 and Supplementary Table 5).

For the birth weight-based PRS, the difference in standardized BMI between the $1^{\text {st }}$ and $10^{\text {th }}$ decile is 0.7 at birth (Figure 6), declines considerably already at six weeks, and then stabilizes. This residual and lasting association of the birth weight PRS supports an overlap between genetic variants influencing birth weight and BMI development in infancy and childhood. Furthermore, the top risk score decile captures an elevated and consistent share of obese children, even until seven to eight years, where it performs similarly to scores trained on childhood BMI and obesity (Figure 6). 
medRxiv preprint doi: https://doi.org/10.1101/2021.05.04.21256508; this version posted May 7, 2021. The copyright holder for this preprint (which was not certified by peer review) is the author/funder, who has granted medRxiv a license to display the preprint in perpetuity.

It is made available under a CC-BY 4.0 International license .

The PRS based on adult BMI displays a shift from three to eight years, where the difference in standardized BMI between the $1^{\text {st }}$ and $10^{\text {th }}$ decile rapidly grows from 0.36 to 0.80 (Figure 6) and variance explained increases from 0.4 to $5.3 \%$ (Figure 6 ). In the top risk decile, $13 \%$ of children were obese at age eight years, corresponding to a 2.6 times higher risk compared to the median at this age, and a 7.4 times higher risk compared to the bottom risk decile. This demonstrates how adult BMI PRSs can detect children who are at considerable risk of becoming obese early in life. The PRS based on childhood BMI and obesity display similar patterns as adult BMI, albeit with lower variance explained (Figure 6). These studies thus mainly capture the genetics of BMI after adiposity rebound, where the adult architecture is already dominating. Results from both the BMI adjusted and unadjusted T2D PRS show an inverse correlation between BMI at birth and later T2D. However, while this effect quickly vanishes for the unadjusted T2D PRS, children in the top risk decile for BMI-adjusted T2D-risk maintain lower BMI throughout infancy, possibly reflecting the key role of insulin metabolism during early growth ${ }^{44}$ (Figure 6, Supplementary Table 5).

\section{Age stratified PRS improves prediction of childhood BMI}

None of the PRS models above capture the BMI development during infancy and the first years of childhood. To evaluate the improvement in predictive performance of PRS models when based on time resolved GWAS-results generated in this study compared to models trained on adult BMI using 1,096 independent children in MoBa. Age-specific modelling vastly improved the variance explained by the PRS during infancy, especially around the adiposity peak at six months, where $\mathrm{R}^{2}$ increased from $1.5 \%$ using results from adult BMI to $6.4 \%$ using age-specific results (Figure 6, Supplementary Table 5). This corresponds to a doubling of the distance between the mean standardized BMI of the top and bottom PRS quintiles, from 0.4 to 0.8 (Figure 6). We also tested the predictive ability of the 21 variants in the Transient cluster, which peaked between six months and 1.5 years $\left(p<1 \times 10^{-5}\right)$, and explained between 3.0 and $4.5 \%$ 
medRxiv preprint doi: https://doi.org/10.1101/2021.05.04.21256508; this version posted May 7, 2021. The copyright holder for this preprint (which was not certified by peer review) is the author/funder, who has granted medRxiv a license to display the preprint in perpetuity.

It is made available under a CC-BY 4.0 International license .

of the variance during this age span. Hence, the identified variants in the Transient cluster alone explain a substantial proportion of the variance in BMI around the adiposity peak. Tracking the share of children in the different risk score strata at each time point yielded interweaved trajectories illustrative of the dramatic changes in the genetics of BMI (Figure 6).

\section{Discussion}

The genetics of BMI changes rapidly during infancy and early childhood, which are stages of life characterized by rapid development and drastic changes in the environment, body composition, and metabolism. From the 46 independent loci that we associate with childhood BMI, 30 are not associated with birth weight or adult BMI in large meta-analyses. We propose to group the genetic association with early BMI into four main clusters that align well with the phases of early growth (Figure 1): the Birth cluster, characterized by loci mainly acting on fetal growth; the Transient and Early Rise clusters that affect BMI development during the key transitions around adiposity peak and rebound; and finally the Late Rise cluster of loci that come into play later in childhood and have persisting influence on BMI into adult life. Most of the variants that we discovered show age-specific transient effects and thus would not be identified from GWASs in other age groups. Conversely, early rising loci display gradually stronger effects after birth lasting into pre-pubertal age. These loci may be particularly important for processes preceding puberty onset, which is supported by the LD score regression profiles that show gradually increasing genetic correlation between BMI at three to eight years of age and early puberty, higher stature at age 10-12 years, and shorter relative length increase after age 12 years. The age-specific association patterns demonstrate a major change in the underlying genetic architecture of childhood BMI pre and post adiposity rebound, where a shift in association trajectories, genetic correlations, PRS prediction power, and heritability occurs. This is further underlined by the large overlap between variants identified in adult BMI and late childhood, but lower overlap with earlier childhood. 
medRxiv preprint doi: https://doi.org/10.1101/2021.05.04.21256508; this version posted May 7, 2021. The copyright holder for this preprint (which was not certified by peer review) is the author/funder, who has granted medRxiv a license to display the preprint in perpetuity.

It is made available under a CC-BY 4.0 International license .

In addition to replicating the association with variants in $L E P / L E P R^{17,18}$, we identify two novel variants in $L E P R$ and variants near PCSK1, $A D C Y 3$ and $M C 4 R$, all known monogenic obesity genes and central to the hypothalamic signalling pathway. All show age-dependent influences during early childhood. Thus, our findings are highly suggestive for energy intake and expenditure being central to controlling BMI during early childhood. As more genes implicated in monogenic obesity are found to harbour common variants associated with BMI, the notion that monogenic and polygenic obesity share underlying etiologies is strengthened.

The bidirectional gut-brain-axis connecting the enteric with the central nervous system plays a vital role in informing the brain of peripheral energy status. However, relatively few genetic variants associated with genes with direct or indirect roles in gastrointestinal functions have been associated with childhood obesity. Thus, identifying a complex signal within GLP1R is particularly intriguing considering its biological prior. First, the discovery of three novel independent associations in GLP1R not picked up in the much bigger meta-analyses on adult $\mathrm{BMI}$ is advocating for distinctly different underlying biology driving early BMI development. Second, it iterates on the importance of hypothalamic signalling and further establishes the importance of common variation in genes related to the gut-brain-axis in development of early childhood BMI. Finally, increased understanding of GLP-1 signalling in early childhood BMI development is particularly important as GLP1R is a proven pharmaceutical target for treating adult obesity ${ }^{45}$ and recently showed promising results for treating obesity in adolescence ${ }^{46}$. As the reluctance to medically treat polygenic childhood obesity might at some point be outweighed by the strong evidence of early childhood obesity persisting into adulthood ${ }^{5}$, GLP1R agonist could prove promising. A study of patients treated with the GLP1R agonist liraglutide found alterations in brain activity related to highly desirable food cues and reduced activity in areas of the brain involved in the reward system ${ }^{47}$. Mice injected with liraglutide show increased energy expenditure through stimulation of brown adipocyte thermogenesis acting through hypothalamic processes $^{48}$. GLP1R expression in adipose tissue has also been linked to insulin sensitivity ${ }^{49}$. 
medRxiv preprint doi: https://doi.org/10.1101/2021.05.04.21256508; this version posted May 7, 2021. The copyright holder for this preprint (which was not certified by peer review) is the author/funder, who has granted medRxiv a license to display the preprint in perpetuity.

It is made available under a CC-BY 4.0 International license.

Child-mother-father trio analyses revealed that the association for two independent loci near $K L F 14$ is driven by the maternal transmitted allele only, suggesting that the paternal allele is silenced. Maternal imprinting for variants in KLF14 has previously been identified for T2D and one of our variants tag the same signal, while the other appears as a novel second imprinting effect acting on KLF14 in early childhood. Additionally, our PRS analysis using a T2D reference study finds persistently low BMI during childhood for children in the highest decile of BMIadjusted T2D PRS, and it is tempting to ascribe these late effects on childhood BMI to mechanisms acting through insulin and glucose metabolism given the numerous studies associating KLF14 with T2D. However, alleles in high LD with the infant BMI and T2D risk increasing alleles were recently associated with lower plasma leptin levels adjusted for $\mathrm{BMI}^{41}$, offering a mechanistic hypothesis and yet another putative link between leptin regulation and weight gain in infancy.

Polygenic risk prediction provides opportunities to estimate an individual-level genetic liability and may potentially be used for early identification of children with considerable risk for developing obesity. Here, we show striking differences in BMI between children in the top and bottom deciles of an adult-BMI based PRS concurrent with timing of the adiposity rebound. Notably, the 0.8 effect difference in standardized BMI between top and bottom decile at age eight in the Norwegian MoBa population is almost identical to what was previously described for British children from ALSPAC ${ }^{10}$, suggesting that this score is transferable between Scandinavian and British children. We also show that the PRS can identify children at considerably higher risk of being obese already from five years of age. As much as $13 \%$ of children in the top decile could be defined as obese at age eight years, corresponding to a seven fold higher risk compared to the bottom risk decile (Figure 5).

The shift in genetic architecture before age five years renders PRSs based on adult BMI inferior to age-resolved scores during infancy. The testing in our independent sample demonstrates that $\mathrm{BMI}$ in the earlier years of life is shaped by a complex interplay and transitions from both age 
medRxiv preprint doi: https://doi.org/10.1101/2021.05.04.21256508; this version posted May 7, 2021. The copyright holder for this preprint (which was not certified by peer review) is the author/funder, who has granted medRxiv a license to display the preprint in perpetuity.

It is made available under a CC-BY 4.0 International license .

restricted and more long-term genetic influences that have to be taken into consideration when evaluating a child's growth pattern and the potential for targeted interventions.

Our study sample consists of a single cohort, all of Northern European ancestry. How generalizable the results are to other populations remains to be evaluated. However, the larger size of the current MoBa release, the availability of parental data and the homogeneous phenotyping allowed us to perform much more detailed time-resolved analyses than typically possible in a meta-analysis involving studies performed under different protocols and data collection timepoints. The age-dependent association patterns identified here illustrate the importance of early age sampling, and the need for unifying data collection and measurements across cohorts to balance the putative benefit from increased sample size without introducing considerable variance in the phenotyping.

In conclusion, our results provide a fine-grained understanding of the changing genetic landscape regulating BMI from birth to eight years. The identified loci represent clusters of association trajectories that reflect various phases of growth and highlight a fundamental role of pathways involved in appetite regulation and energy metabolism in both normal growth and rare syndromic obesity. These results demonstrate a strong genetic drive ensuring that children gather the energy necessary to sustain healthy growth. 


\section{Methods}

\section{Study population}

The Norwegian Mother, Father and Child Cohort Study (MoBa) is an open-ended cohort study that recruited pregnant women in Norway from 1999 to 2008. Approximately 114,500 children, 95,200 mothers, and 75,000 fathers of predominantly Norwegian ancestry were enrolled in the study from 50 hospitals all across Norway ${ }^{22}$. Anthropometric measurements of the children were carried out at hospitals at birth and during routine visits in the primary health care system by trained nurses at 6 weeks, 3, 6, 8 months, and 1, 1.5, 2, 3, 5, 7, and 8 years of age. Parents later transcribed these measurements to questionnaires. In 2012, the project Better Health by Harvesting Biobanks (HARVEST) randomly selected 11,490 umbilical cord blood DNA samples from the biobank of this study for family triad genotyping, excluding samples matching any of the following criteria: (1) stillborn, (2) deceased, (3) twins, (4) non-existing data at the Norwegian Medical Birth Registry, (5) missing anthropometric measurements at birth in Medical Birth Registry, (6) pregnancies where the mother did not answer the first questionnaire (as a proxy for higher dropout rate), and (7) missing parental DNA samples. In 2016, HARVEST randomly selected a second set of 8,900 triads using the same criteria. The same year NORMENT selected 5,910 triads with the same selection criteria as HARVEST, and extended this with 3,209 triads in 2018. Additionally, a study from 2014 genotyped 1,062 ADHD cases among the children and in 2015 a study genotyped 5,834 randomly selected parents.

\section{Genotyping}

Genotyping of the samples was performed in seven different batches on different Illumina platforms over a period of four years. SELECTionPREDISPOSED and HARVEST genotyped using Illumina HumanCoreExome-12 v.1.1 and HumanCoreExome-24 v.1.0 arrays for 6,938 
medRxiv preprint doi: https://doi.org/10.1101/2021.05.04.21256508; this version posted May 7, 2021. The copyright holder for this preprint (which was not certified by peer review) is the author/funder, who has granted medRxiv a license to display the preprint in perpetuity.

It is made available under a CC-BY 4.0 International license.

and 4,552 triads, respectively, at the Genomics Core Facility located at the Norwegian University of Science and Technology, Trondheim, Norway. The second wave of genotyping in HARVEST genotyped using Illumina's Global Screening Array v.1.0 for all 8,900 triads at the Erasmus University Medical Center in Rotterdam, Netherlands. NORMENT genotyped 5,910 triads using InfiniumOmniExpress-24v1.2 in 2016 and 3,209 samples using GSA24-v1.0 in 2018. The 1,062 ADHD cases were genotyped using InfiniumOmniExpress-24v1.2 in 2014 and the 5,834 randomly selected controls using HumanOmniExpress-24-v1.0. All were genotyped at deCODE genetics, Reykjavik, Iceland. The Genome Reference Consortium Human Build 37 (GRCh37) reference genome was used for all annotations.

Genotypes were called in Illumina GenomeStudio v.2011.1 for the 11,490 triads part of HARVEST and v.2.0.3 for the remaining batches. Cluster positions were identified from samples with call rate $\geq 0.98$ and GenCall score $\geq 0.15$. We excluded variants with low call rates, signal intensity, quality scores, and deviation from Hardy-Weinberg equilibrium (HWE) based on the following QC parameters: call rate $<98 \%$, cluster separation $<0.4,10 \%$ GC-score $<0.3$, AA T Dev $>0.025$, HWE $p$-value $<1 \times 10^{-6}$. Samples were excluded based on call rate $<98 \%$ and heterozygosity excess > 4 SD. Study participants with non-Norwegian ancestry were excluded after merging with ancestry reference samples from the HapMap project (ver. 3).

\section{Pre-phasing and imputation}

Prior to imputation, insertions and deletions were removed to make the dataset congruent with Haplotype Reference Consortium (HRC) v.1.1 imputation panel using HRC Imputation preparation tool by Will Rayner version 4.2 .5 (see URLs). Allele, marker position, and strand orientation were updated to match the reference panel. Pre-phasing was conducted locally using Shapeit v2.79050. Imputation was performed at the Sanger Imputation Server (see URLs) with positional Burrows-Wheeler transform ${ }^{51}$ and HRC version 1.1 as reference panel. 
medRxiv preprint doi: https://doi.org/10.1101/2021.05.04.21256508; this version posted May 7, 2021. The copyright holder for this preprint (which was not certified by peer review) is the author/funder, who has granted medRxiv a license to display the preprint in perpetuity.

It is made available under a CC-BY 4.0 International license .

\section{Phenotypes}

Length/height and weight values were extracted from hospital records through the Norwegian Medical Birth Registry for measurements at birth, and from the study questionnaires for remaining time points. In addition, pregnancy duration in days calculated from ultrasound due date was obtained from the Norwegian Medical Birth Registry. Length and weight values were inspected at each age and those provided in centimetre or gram instead of meter and kilogram, respectively, were converted. Extreme outliers, typically an error in handwritten text parsing or a consequence of incorrect units, were excluded. A value $x$ was considered as an extreme outlier if $x>m+2 \times\left(\right.$ perc $\left._{99}-m\right)$ or $x<m-2 \times\left(m-\right.$ perc $\left._{1}\right)$, where $m$ represents the median within the age group and perc $_{1}$ and $p e r c_{99}$ the $1^{\text {st }}$ and $99^{\text {th }}$ percentiles, respectively.

\section{Outlier detection and missing value imputation}

For all children in MoBa ( $\mathrm{M}$ 100,000), length and weight curves were inspected for outlying values, missing values were imputed, and artefacts causing the length of kids to decrease were corrected. Outlier detection, missing value imputation, and length decrease correction was conducted as described previously ${ }^{17}$. In brief, length and weight values presenting an extreme peak or an extreme gap were removed. Missing values preceded and followed by at least two measurement points were imputed by interpolating over the growth curve. Length curves were adjusted to prevent peaks to cause length decrease. These steps were conducted iteratively until no data point was changed, as detailed in Supplementary Figure 1. Finally, for all children and all time points presenting both length and weight values, the BMI was computed.

\section{Sample selection}

From the total set of growth curves, only the genotyped children were retained. In addition, the following pregnancies were excluded: 1) pregnancies strictly shorter than 37 full gestational 
medRxiv preprint doi: https://doi.org/10.1101/2021.05.04.21256508; this version posted May 7, 2021. The copyright holder for this preprint (which was not certified by peer review) is the author/funder, who has granted medRxiv a license to display the preprint in perpetuity. It is made available under a CC-BY 4.0 International license .

weeks (259 days); 2) plural pregnancies; 3) ADHD excess cases. The set of ADHD excess were defined as the additional cases included by the ADHD case/control study. The resulting set of 28,681 children of Norwegian ancestry was used in genetic association and is referred to in the following as the full set of children. From this, we built a set of child-mother-father trios by selecting children who had both parents genotyped, with parents passing genotype QC and being of Norwegian ancestry according to the PCA. If the members of two different trios were related according to the IBD analysis $\left(\mathrm{PI} \_\right.$HAT $\left.>0.1\right)$, one trio was excluded. The resulting set of 23,538 trios is referred to in the following as the set of unrelated trios. Throughout the text, allele frequencies are estimated based on the parents in the set of unrelated trios. Similarly, the level of Linkage Disequilibrium (LD) annotated in Figures 4 and Figure 5 is estimated based on the parents in the set of unrelated trios.

\section{Phenotypes standardization}

For the full set of children, at each time point, the BMI was standardized using the generalized additive model for location, scale and shape (GAMLSS) v5.1-7 (gamlss.com) in R v. 3.6.1 (2019-07-05) -- "Action of the Toes". Two GAMLSS models based on a Log Normal distribution were fitted separately for boys and girls, using pregnancy duration as covariate, as detailed in Table Phenotypes Standardization. Note that the models of early BMI include a non-linear dependency on pregnancy duration, but the non-linear terms had to be removed after six months to ensure the convergence of GAMLSS. GAMLSS models were fitted solely on children from the set of unrelated trios. The models obtained were used to compute standardized BMI values for the full set of children, i.e. including related children, using the 'centiles.pred' function of GAMLSS. Throughout the text, all effect sizes are expressed relative to the standardized phenotypes. Please note that standardization approaches vary between the present study and the meta analyses on birth weight ${ }^{24}$ and adult $\mathrm{BMI}^{13}$, notably with regards to scale and covariates, which might impair the comparability of association results. A child was considered 
medRxiv preprint doi: https://doi.org/10.1101/2021.05.04.21256508; this version posted May 7, 2021. The copyright holder for this preprint (which was not certified by peer review) is the author/funder, who has granted medRxiv a license to display the preprint in perpetuity.

It is made available under a CC-BY 4.0 International license .

obese if the standardized BMI was strictly higher than qnorm(0.95) where qnorm represents the quantile function of the standard normal distribution.

\begin{tabular}{|l|l|l|}
\hline Parameter & Value at birth and 6 weeks & Value at later time points \\
\hline Formula & bmi $\sim \mathrm{fp}$ (pregnancy_duration) & bmi $\sim$ pregnancy_duration \\
\hline Sigma Formula & $\sim \mathrm{fp}$ (pregnancy_duration) & $\sim$ pregnancy_duration \\
\hline Family & LOGNO & LOGNO \\
\hline
\end{tabular}

Table Phenotypes Standardization. Parameters provided to GAMLSS to fit the distribution of children $B M I$ at different time points: formula, sigma formula, and family. Models at birth and 6 weeks differ from those at later time points as they account for non-linearity, indicated by the fractional polynomial expansion term fp in the formulas. LOGNO represents the Log Normal distribution.

\section{Genetic association}

The association between the genotypes and the standardized phenotypes using linear mixed models was conducted using BOLT-LMM v2.3.4 ${ }^{52}$ in the full set of children. The covariates used were the genotyping batch, sex, pregnancy duration, and ten principal components. LD scores were taken from samples of European ancestry in the 1000 Genomes Project ${ }^{53}$, and the genetic map files embedded with BOLT-LMM. The GRM used in the analyses was calculated using a set of high quality markers having both MAF $>0.05$ and INFO score $>0.98$. A genetic variant was deemed genome-wide significant if presenting a $p$-value $<5 \times 10^{-8}$ at any given time point. At all loci reaching genome-wide significance, approximate conditional and joint multiple singlenucleotide polymorphism (SNP) analyses were conducted using COJO in GCTA 1.93.2b ${ }^{23}$. Throughout all analyses, the age at peak association refers to the age of lowest p-value in the association with BMI, and the effect allele refers to the BMI-increasing allele at age at peak association. 
medRxiv preprint doi: https://doi.org/10.1101/2021.05.04.21256508; this version posted May 7, 2021. The copyright holder for this preprint (which was not certified by peer review) is the author/funder, who has granted medRxiv a license to display the preprint in perpetuity.

It is made available under a CC-BY 4.0 International license.

\section{Obesity gene enrichment analysis}

The gene enrichment analysis around the 46 top hits was conducted using the union of two panels of genes implicated in monogenic and severe early onset obesity: Blueprint Genetics Monogenic Obesity Panel (test code KI1701)

(blueprintgenetics.com/tests/panels/endocrinology/monogenic-obesity-panel) consisting of 36 genes, and Genomics England severe early-onset obesity panel v.2.2 consisting of 32 genes (panelapp.genomicsengland.co.uk/panels/130). The union of the two resulted in 42 genes used in analysis. A list containing gene locations for hg19 were obtained from PLINK 1.9 resources (cog-genomics.org/plink/1.9/resources). The list contained 25,303 unique genes used in the analysis. A $500 \mathrm{~kb}$ window was used to identify genes in the vicinity of the top hits. The significance for the enrichment of monogenic genes compared to random sampling was estimated using the distribution function of the Hypergeometric distribution via the function phyper from the R package stats.

\section{Comparison with adult BMI in MoBa}

Pre-pregnancy BMI values were computed using self-reported height and weight for the parents who were genotyped, passed QC, and of core Norwegian ancestry $(27,088$ mothers and 26,239 fathers), yielding 26,062 and 22,719 values for mothers and fathers, respectively. As detailed in Table Parent Phenotypes Standardization, BMI values were standardized using GAMLSS for mothers and fathers separately, using their birth year as covariate, as a proxy for age. Like for children, GAMLSS models were fitted solely on parents from the set of unrelated trios, and used to compute standardized values for all parents, i.e. including related parents. 


\begin{tabular}{|l|l|}
\hline Parameter & Value \\
\hline Formula & bmi $\sim \mathrm{fp}$ (birth_year) \\
\hline Sigma Formula & $\sim \mathrm{fp}$ (birth_year) \\
\hline Family & LOGNO \\
\hline
\end{tabular}

Table Parent Phenotypes Standardization: Parameters provided for GAMLSS to model parental prepregnancy BMI: formula, sigma formula, and family. Note that mothers and fathers were standardized separately. LOGNO represents the Log Normal distribution.

The association between parent BMI and genotypes was computed for mothers and fathers separately, using BOLT-LMM v2.3.4 ${ }^{52}$ as done for the children. The covariates used were the genotyping batch, birth year, and ten principal components.

\section{Clustering of association profiles}

For each of the 46 independent genome-wide significant variants, alleles were aligned so that the association with standardized BMI is positive at the age of peak association. Effect sizes for all time points were then combined into an association profile for this variant, i.e. a vector $\beta=$ $\left.\left(\beta_{\text {birth }}, \beta_{6 w}, \ldots, \beta_{8 y}\right)\right)$. Reference effect size over time profiles corresponding to an association at birth waning afterwards, and an increasing association after one year of age towards adulthood were built using equations 1 and 2 , respectively.

$$
\begin{gathered}
x_{1}(\text { age })=10^{-3 \frac{a g e}{365.25}} \text { (1) } \\
x_{2}(\text { age })=0 \text { if age }<365.25,\left(\frac{\text { age }-365.25}{7 \times 365.25}\right)^{2} \text { else }
\end{gathered}
$$

Where $x_{1}$ and $x_{2}$ represent the reference profiles and age is the age at a given time point in days. The association profiles of each variant were then projected onto these reference profiles, by fitting a linear model:

$$
\beta \sim \mathrm{x}_{1}+\mathrm{x}_{2}+1
$$


medRxiv preprint doi: https://doi.org/10.1101/2021.05.04.21256508; this version posted May 7, 2021. The copyright holder for this preprint (which was not certified by peer review) is the author/funder, who has granted medRxiv a license to display the preprint in perpetuity.

It is made available under a CC-BY 4.0 International license .

The resulting projection is shown in Figure 1B. The profiles of equation 1 and 2 correspond to the curves on the West and South cardinal directions of Figure 1B, the profiles in all other cardinal and intercardinal directions correspond to linear combinations of these two, yielding eight reference profiles: (SE) early fall and late rise, (E) early fall, (NE) early and late fall, (N) late fall, (NW) early rise and late fall, (W) early rise, (SW) early rise and late rise, and (S) late rise.

Each variant was plotted on Figure $1 \mathrm{~B}$ using the sum of the absolute values of the effect size over time as radial coordinate, and the relative association with $x_{1}$ and $x_{2}$ to define the angular coordinate, as described in equations 4 and 5 , respectively.

$$
\begin{gathered}
\rho=\Sigma|\beta| \\
\theta=-\operatorname{atan} 2\left(\beta_{x_{2}}, \beta_{x_{1}}\right)+\theta_{0}
\end{gathered}
$$

Where $\rho$ represents the radial coordinate, $\theta$ the angular coordinate, $\beta_{x_{1}}$ and $\beta_{x_{2}}$ the association between the genetic association profile and the reference profiles $x_{1}$ and $x_{2}$, respectively, and $\theta_{0}$ a constant. Each association profile was plotted after normalization to the association level at age at peak in Figure $1 \mathrm{C}$ using the angular coordinate $\theta$ as baseline on the ordinate. A cardinal or intercardinal cluster was defined for each of the eight reference profiles corresponding to the cardinal and intercardinal directions in Figure 1B. Every cardinal and intercardinal cluster was assigned a first element chosen to be the variant with the angular coordinate $\theta$ closest to the direction (i.e. most correlated to that profile). The other variants were then assigned to a cluster based on their angular nearest neighbour, yielding the clustering displayed by the dendrogram of Figure 1D. Finally, as illustrated in Figure 1E, the cardinal and intercardinal clusters were grouped into four main clusters: (Birth) $\mathrm{SE}+\mathrm{E}+\mathrm{NE}$; (Transient) $\mathrm{N}+$ $\mathrm{NW}$; (Early rise) $\mathrm{W}$; and (Late Rise) $\mathrm{SW}+\mathrm{S}$. 
medRxiv preprint doi: https://doi.org/10.1101/2021.05.04.21256508; this version posted May 7, 2021. The copyright holder for this preprint (which was not certified by peer review) is the author/funder, who has granted medRxiv a license to display the preprint in perpetuity.

It is made available under a CC-BY 4.0 International license.

\section{Mapping to pathways}

The lead SNP of the 46 independent loci were submitted to the Ensembl Variant Effect Predictor $(\mathrm{VEP})^{54}$. All proteins coded by genes reported with a consequence other than downstream_gene_variant, upstream_gene_variant, or intergenic_variant were retained as potentially affected by a given variant. If no such gene was found, the protein coded by the closest gene within $500 \mathrm{~kb}$ was retained. Proteins were matched to Reactome ${ }^{55}$ using PathwayMatcher ${ }^{56}$. Then, for each of the four main clusters, we built the smallest set of top-level pathways that explained the protein set returned by the VEP analysis, counted the number of variants in this cluster affecting a protein in one of these top-level pathways (Figure 1F).

\section{Mapping to other traits}

For each SNP, other associated traits were extracted using PhenoScanner ${ }^{57,58}$. PhenoScanner was queried using EUR and an $\mathrm{R}^{2}$ threshold of 0.8 for proxies and $5 e-8$ as $\mathrm{p}$-value threshold. Synonymous terms were grouped, and, for each of the four main clusters, the number of variants mapping to a given trait relative to the number of variants in the cluster was plotted in Figure 1G.

\section{Comparison with birth weight and adult BMI}

Summary statistics on birth weight and adult BMI were obtained from Warrington et al. ${ }^{24}$ and Yengo et al. ${ }^{13}$, respectively. Variants were matched by rsid. For the variants with no match, proxies were sought using LDproxy (Idlink.nci.nih.gov) using a window of $500 \mathrm{~kb}, \mathrm{CEU}$ as reference population, and an $\mathrm{R}^{2}$ threshold of 0.2 , and alleles were aligned. From the 46 top hits, variants were considered independent of the hits in Warrington et al. ${ }^{24}$ and Yengo et al. ${ }^{13}$ if the matched SNP had a p-value higher than $5 \times 10^{-8}$. In addition, for each of the 46 top hits, the variant in Warrington et al. ${ }^{24}$ and Yengo et al. ${ }^{13}$ with the lowest $p$-value with an LD $\mathrm{R}^{2}$ value 
medRxiv preprint doi: https://doi.org/10.1101/2021.05.04.21256508; this version posted May 7, 2021. The copyright holder for this preprint (which was not certified by peer review) is the author/funder, who has granted medRxiv a license to display the preprint in perpetuity.

It is made available under a CC-BY 4.0 International license.

higher or equal to 0.2 was extracted. Summary statistics for all variants in the three data sets are available in Supplementary Table 6.

Subsequently, for all variants associated with own birth weight in Warrington et al. ${ }^{24}$, and all variants associated with adult BMI in Yengo et al. ${ }^{13}$, the association profile in MoBa was extracted and the angular coordinate of Figure 1B was computed by projecting onto the reference profiles as before. The angular density of each study was subsequently computed using sliding windows over $\theta$, normalized to the number of variants in each study, and plotted in Figure $1 \mathrm{H}$.

\section{Child-mother-father trio and haplotype analysis}

At all time points, for all 46 independent genome-wide significant variants, the association with the children genome was conditioned on the genomes of the parents in the set of unrelated trios using the linear model described in equation 6.

$$
\text { bmi child + mother }+ \text { father }+1
$$

Where bmi refers to the standardized BMI of the child at a given time point, and child, mother, and father the number of tested alleles for this variant in the child, mother, and father genomes, respectively. Note that the number of alleles were taken from genotype hard calls and not genotyping probabilities.

Taking advantage of the phasing of the children genotypes, we could infer the parent-of-origin of the genotyped alleles as done by Chen et al. ${ }^{59}$. This results in an alternative model that allows studying the association per haplotype in the set of unrelated trios, as detailed in equation 7.

$$
\mathrm{bmi} \sim \mathrm{MnT}+\mathrm{MT}+\mathrm{FnT}+\mathrm{FT}+1
$$

Where $M n T$ and $M T$ refer to the number of tested alleles non-transmitted and transmitted by the mother to the child, respectively. Similarly, FnT and FT refer to the number of tested alleles nontransmitted and transmitted by the father to the child, respectively. 
medRxiv preprint doi: https://doi.org/10.1101/2021.05.04.21256508; this version posted May 7, 2021. The copyright holder for this preprint (which was not certified by peer review) is the author/funder, who has granted medRxiv a license to display the preprint in perpetuity.

It is made available under a CC-BY 4.0 International license .

For a given variant, the share of Mendelian errors in the set of unrelated trios was estimated using trios presenting a homozygous parent. Then, a Mendelian error results in a value of -1 or +2 in the non-transmitted allele count. The share of Mendelian error was estimated by comparing the number of such erroneous genotypes to the number of trios with a homozygous parent expected from the tested allele frequency. When the estimated share of Mendelian errors was over $50 \%$, the alleles of the children were swapped.

For the chromosome $\mathrm{X}$, no filtering was done based on ploidy, when only one chromosome was found the allele was assumed to be inherited from the mother. Note that the chromosome $\mathrm{X}$ was not phased, yielding a high share of Mendelian errors, approximately $50 \%$, indicative of a random assignment of children alleles. Haplotype analysis was therefore not possible for the variant on chromosome $\mathrm{X}$, while trio analysis is unaffected by this.

For both models, the same covariates were used as for the genetic association analysis using BOLT-LMM, i.e. genotyping batch, sex, gestational age, and ten principal components, and both phenotypes and genotypes were adjusted for covariates in the same way as BOLT-LMM does. Haplotype and trio analyses were conducted using TrioGen v. 0.5.0 (github.com/mvaudel/TrioGen) in the OpenJDK Runtime Environment (Zulu 8.20.0.5-linux64) (build 1.8.0_121-b15). Summary statistics for all variants are available in Supplementary Table 4.

\section{LD score regression}

LD score regression was performed with LD Hub v.1.9.0 using LDSC v.1.0.027 using all markers remaining after filtering on the provided SNP-list as recommended by the LD Hub authors. A total of 1,215,001 markers remained after filtering. All available phenotypes were selected for correlation analyses. Results for all variables along with heritability and QC reports are available in Supplementary Table 7. 
medRxiv preprint doi: https://doi.org/10.1101/2021.05.04.21256508; this version posted May 7, 2021. The copyright holder for this preprint (which was not certified by peer review) is the author/funder, who has granted medRxiv a license to display the preprint in perpetuity.

It is made available under a CC-BY 4.0 International license.

\section{Polygenic risk scores (PRS)}

PRSs were calculated using PRSice-2 v. 2.3.0 (prsice.info). For scores based on study results from previous meta-analyses, the results were obtained from EGG (egg-consortium.org) for birth weight, childhood BMI and childhood obesity, GIANT for adult BMI (portals.broadinstitute.org/collaboration/giant), and DIAGRAM (diagram-consortium.org) for type 2 diabetes (T2D). PRSs were calculated separately for all time points per phenotype using ten principal components, sex, gestational age, and genotyping batch as covariates. The target dataset included all markers available after imputation. From the full set of children, one in each pair of samples with PI_HAT > 0.1 was removed at random, leaving 25,113 samples for the PRS analyses. Time-resolved scores used age-specific summary results from the primary analyses as base with the independent set of 1,062 samples from MoBa as target. Here, ten principal components, sex, and gestational age were used as covariates. Defaults were used for all other parameters.

\section{Figures}

All figures in the manuscript were generated in R version 3.6.1 (2019-07-05) -- "Action of the Toes" (R-project.org). In addition to the base packages, the following packages were used: tidyr version 1.1.0, janitor version 2.0.1, conflicted version 1.0.4, glue version 1.4.0, stringr version 1.4.0, dplyr version 1.0.0, scico version 1.1.0, RColorBrewer version 1.1-2, ggplot2 version 3.3.2, ggrepel version 0.8.2, grid version 3.6.1, gtable version 0.2.0, patchwork version 1.1.1, phenoscanner version 1.0, ggfx version 0.0.0.900. 
medRxiv preprint doi: https://doi.org/10.1101/2021.05.04.21256508; this version posted May 7, 2021. The copyright holder for this preprint (which was not certified by peer review) is the author/funder, who has granted medRxiv a license to display the preprint in perpetuity. It is made available under a CC-BY 4.0 International license.

\section{URLS}

HRC or 1000G Imputation preparation and checking: well.ox.ac.uk/ wrayner/tools

Sanger Imputation Service, imputation.sanger.ac.uk

LD Score repository, data.broadinstitute.org/alkesgroup/LDSCORE

GTEx, the Genotype-Tissue Expression portal, gtexportal.org

\section{Data availability}

Summary data from the discovery analysis is available for download at the Norwegian Mother, Father and Child Cohort Study website (fhi.no/en/studies/moba). Access to genotypes and phenotypes can be obtained by direct request to the Norwegian Institute of Public Health (fhi.no/en/studies/moba/for-forskere-artikler/gwas-data-from-moba).

\section{Ethics}

Informed consent was obtained from all study participants. The administrative board of the Norwegian Mother, Father and Child Cohort Study led by the Norwegian Institute of Public Health approved the study protocol. The establishment of MoBa and initial data collection was based on a license from the Norwegian Data Protection Agency and approval from The Regional Committee for Medical Research Ethics. The MoBa cohort is currently regulated by the Norwegian Health Registry Act. The study was approved by The Regional Committee for Medical Research Ethics (\#2012/67). 


\section{Author contributions}

$\varnothing . H .$, M.V., P.R.N. and S.J. designed the study. $\varnothing . H$. and M.V. analysed the data. $\varnothing . H .$, M.V., and S.J. interpreted the data. J.J., J.B., G.P.K., T.R.K., P.M., C.S., O.A.A. contributed to sample acquisition and genotyping. J.J. and J.B. assisted with genotype quality control. P.S.N., C.F., I.L.K., B.B.J., B.J., and P.R.N. critically revised the manuscript for important intellectual content. $\varnothing . H .$, M.V., and S.J. wrote the manuscript. All authors participated in preparing the manuscript by reading and commenting on drafts before submission. P.R.N. and S.J. acquired the funding.

\section{Competing interests}

OAA is a consultant to HealthLytix. The other authors declare no competing interests.

\section{Acknowledgements}

This work was supported by grants (to S.J) Helse Vest's Open Research Grant (grants \#912250 and F-12144), the Novo Nordisk Foundation (grant NNF19OC0057445 ) and the Research Council of Norway (grant \#315599)); and (to P.R.N.) from the European Research Council (AdG SELECTionPREDISPOSED \#293574), the Bergen Research Foundation ("Utilizing the Mother and Child Cohort and the Medical Birth Registry for Better Health"), Stiftelsen Kristian Gerhard Jebsen (Translational Medical Center), the University of Bergen, the Research Council of Norway (FRIPRO grant \#240413), the Western Norway Regional Health Authority (Strategic Fund "Personalized Medicine for Children and Adults"), the Novo Nordisk Foundation (grant \#54741), and the Norwegian Diabetes Association. This work was partly supported by the Research Council of Norway through its Centres of Excellence funding scheme (\#262700, \#223273), Better Health by Harvesting Biobanks (\#229624) and The Swedish Research 
medRxiv preprint doi: https://doi.org/10.1101/2021.05.04.21256508; this version posted May 7, 2021. The copyright holder for this preprint (which was not certified by peer review) is the author/funder, who has granted medRxiv a license to display the preprint in perpetuity. It is made available under a CC-BY 4.0 International license.

Council, Stockholm, Sweden (2015-02559), The Research Council of Norway, Oslo, Norway (FRIMEDBIO \#547711, \#273291), March of Dimes (\#21-FY16-121). The Norwegian Mother, Father and Child Cohort Study is supported by the Norwegian Ministry of Health and Care Services and the Ministry of Education and Research, NIH/NIEHS (contract no N01-ES-75558), NIH/NINDS (grant no.1 UO1 NS 047537-01 and grant no.2 UO1 NS 047537-06A1). We are grateful to all the families in Norway who are taking part in this ongoing cohort study. All analyses were performed using digital labs in HUNT Cloud at the Norwegian University of Science and Technology, Trondheim, Norway. 
medRxiv preprint doi: https://doi.org/10.1101/2021.05.04.21256508; this version posted May 7, 2021. The copyright holder for this preprint (which was not certified by peer review) is the author/funder, who has granted medRxiv a license to display the preprint in perpetuity.

It is made available under a CC-BY 4.0 International license.

\section{Figures}




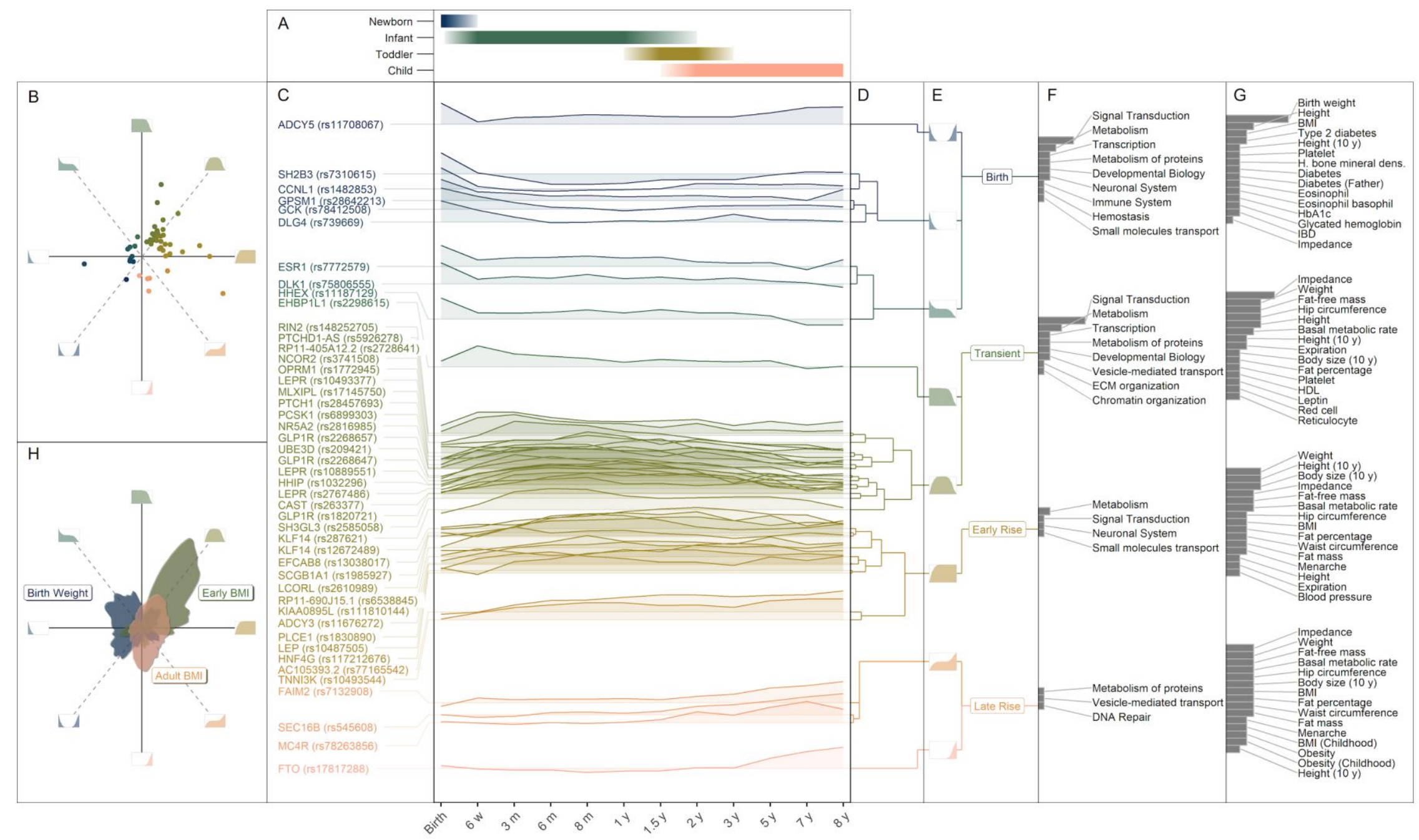

Figure 1 - Longitudinal association effect size profiles for the 46 top hits. (A) Age span of the early childhood developmental stages covered by this association study with BMI. (B) Quadrant plot of the 46 top hits where the radial and angular coordinates of a SNP respectively indicate the magnitude and shape of the effect size profile over time. Inserts at cardinal and intercardinal directions indicate the association profile represented by a given angular coordinate. (C) Effect sizes at the different time points grouped by profile similarity. (D) Dendrogram of the effect size profiles clustering. (E) Grouping of effect size profiles into four main clusters: Birth, Transient, Early Rise, and Late Rise. Inserts to the left indicate the 
association profiles in each cluster. (F) Overlap with top-level biological pathways. Bars represent the number of variants in a cluster mapping a given pathway. (G) Comparisons with other GWAS studies present in PhenoScanner. Bars represent the number of variants associated with a trait $\left(p\right.$-value $\left.5 \times 10^{-8}\right)$. (H) Angular density of beta profiles for variants associated with birth weight (blue), and adult BMI (red), compared to early BMI (green) according to 24,13 , and this study, respectively, and processed as in 1B. See methods for details. 
medRxiv preprint doi: https://doi.org/10.1101/2021.05.04.21256508; this version posted May 7, 2021. The copyright holder for this preprint (which was not certified by peer review) is the author/funder, who has granted medRxiv a license to display the preprint in perpetuity.

\section{It is made available under a CC-BY 4.0 International license .}

A

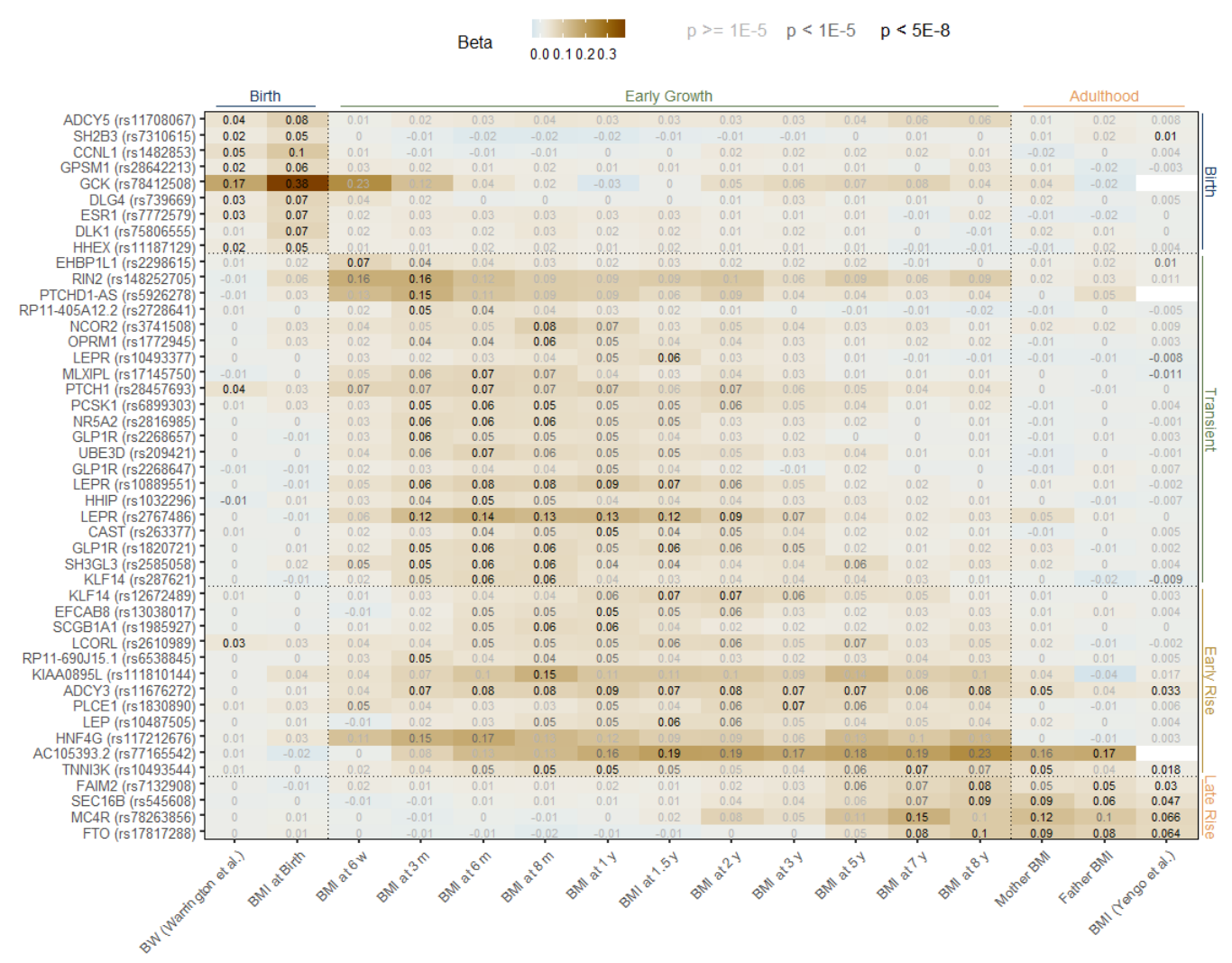

B

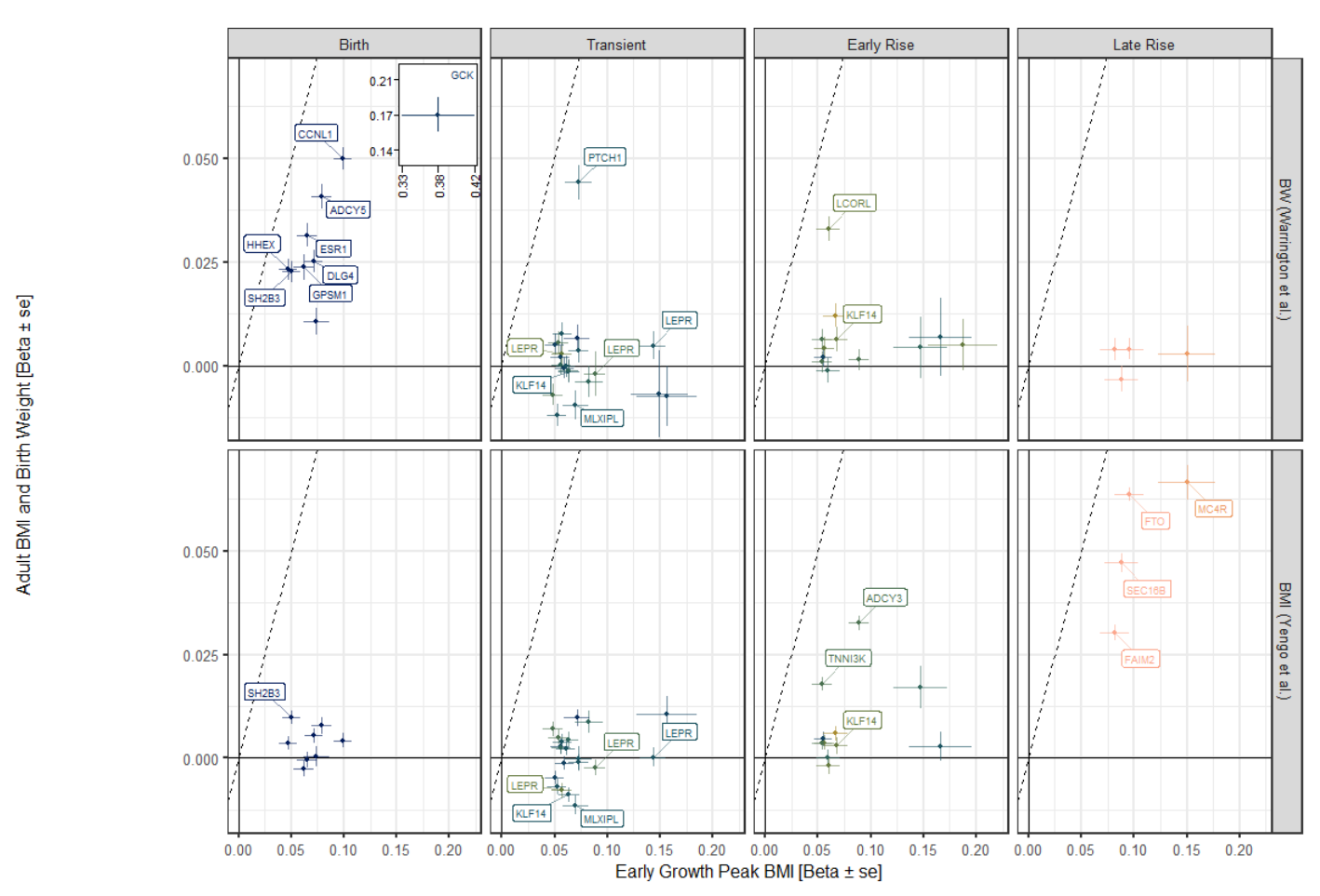

Figure 2 - Comparison with previous studies on birth weight and adult BMI. (A) Heatmap of the effect size for the 46 top hits from birth to adulthood. Variants are ordered vertically according to Figure 
medRxiv preprint doi: https://doi.org/10.1101/2021.05.04.21256508; this version posted May 7, 2021. The copyright holder for this preprint (which was not certified by peer review) is the author/funder, who has granted medRxiv a license to display the preprint in perpetuity. It is made available under a CC-BY 4.0 International license .

1C. The estimated effect size for association with birth weight Warrington et al. ${ }^{24}$ (column 1), BMI during early growth (this study, column 2-12), and adult BMI (mothers and fathers in this study (column 13-14) and Yengo et al. ${ }^{13}$ (last column)) is displayed in each cell. The cell colour represents the estimated effect size and the text colour represents the association p-value. Empty cells indicate that no proxy could be found for the given variant in the given study. See methods for details. (B) Scatter plot of the estimated effect size for association with birth weight ${ }^{24}$ and adult BMI ${ }^{13}$ plotted against the estimated effect size at the age of peak association during early growth (this study). Dashed line indicates equal effect sizes in both studies. The colour represents the age of peak association, as defined as the age with lowest $p$ value. Variants are grouped according to their profile cluster as defined in Figure 1E. Error bars represent one standard error estimate on each side of the effect size estimate. Note that for the sake of readability, GCK at birth is plotted in an insert with a different scale. 

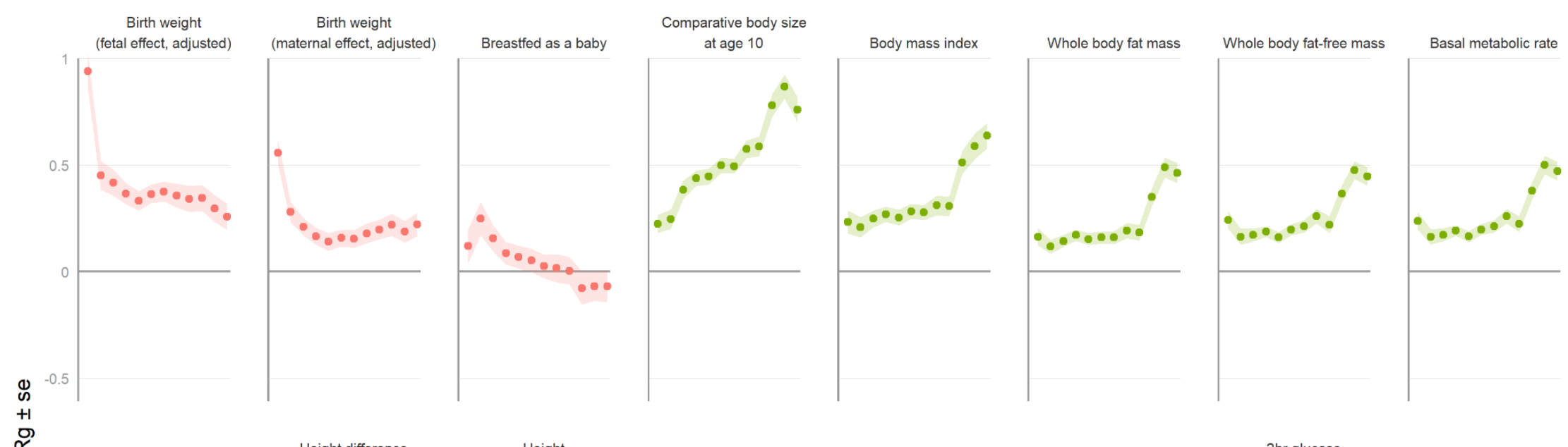

Age at Menarche
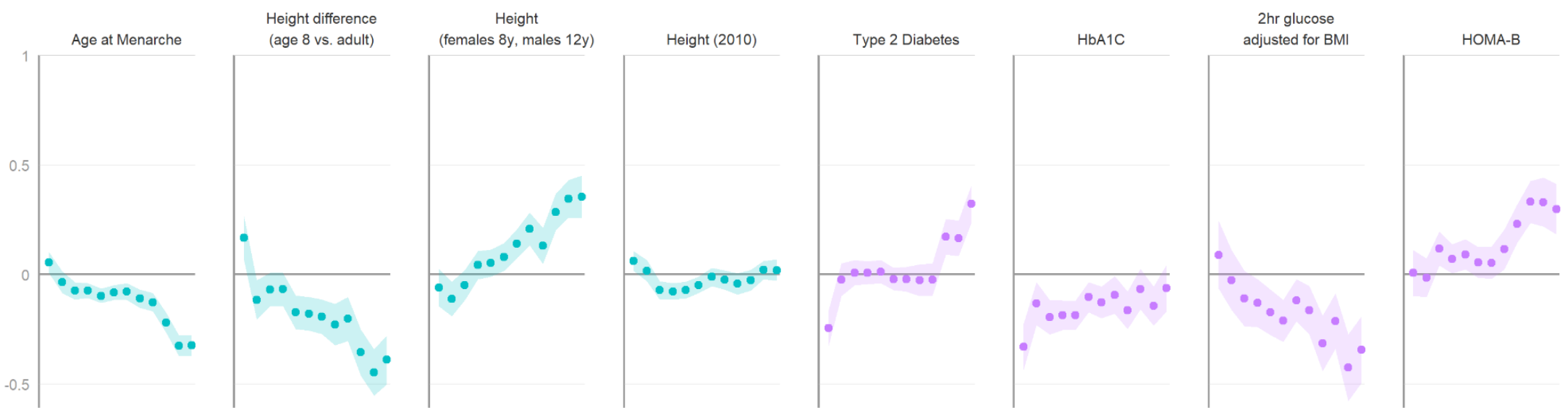

Figure 3 - LD-score regression. Genetic correlation, $r_{g}$, of selected traits with early growth BMI at birth, 6 weeks, 3, 6, 8 months, and 1, 1.5, 2, 3, 5,7 , and 8 years of age. Ribbons represent one standard error estimate on each side of the $r_{g}$ estimate. See methods for details and Supplementary Table 7 for correlation with other traits. 
medRxiv preprint doi: https://doi.org/10.1101/2021.05.04.21256508; this version posted May 7, 2021. The copyright holder for this preprint (which was not certified by peer review) is the author/funder, who has granted medRxiv a license to display the preprint in perpetuity.

\section{It is made available under a CC-BY 4.0 International license .}

A

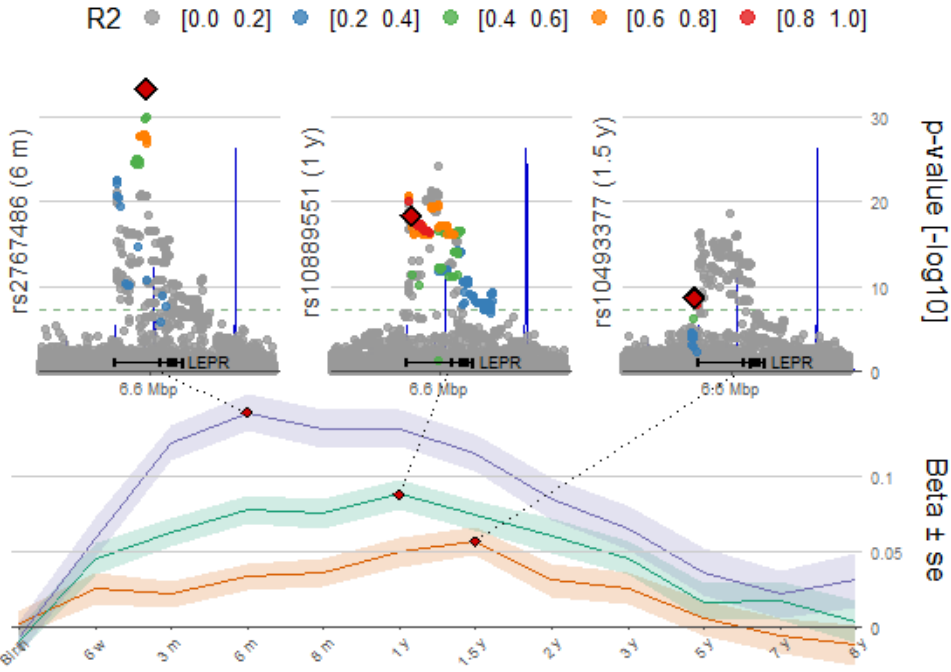

B

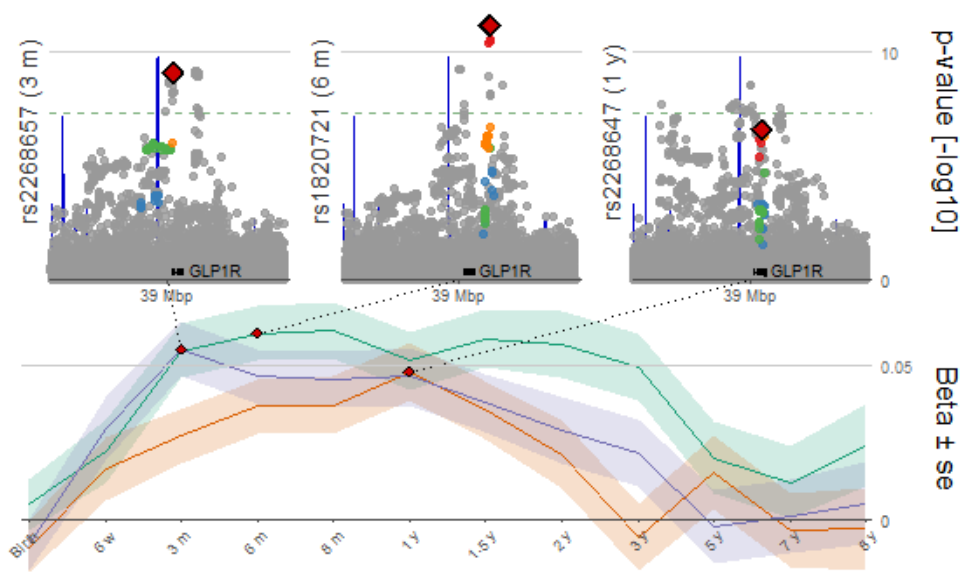

C
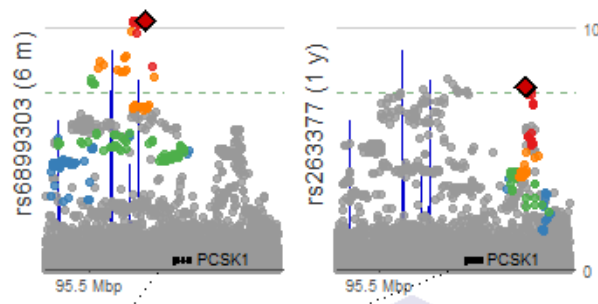

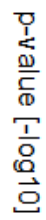
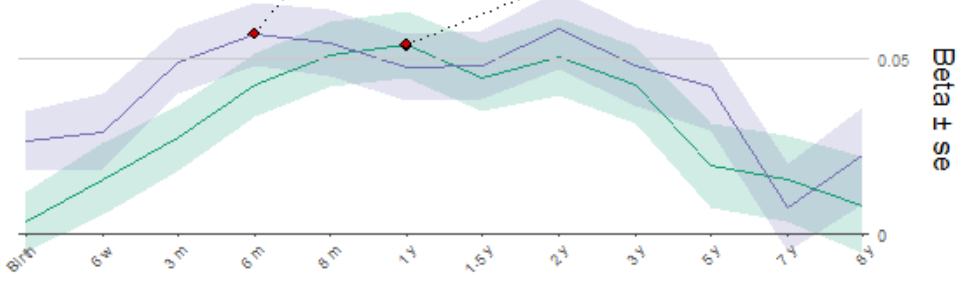

Figure 4 - Loci with multiple independent associations signals. Association profiles with child BMI from birth to eight years of age for the lead SNPs of the signals near (A) LEPR, (B) GLP1R, and (C) PCSK1. Ribbons represent one standard error estimate on each side of the effect size estimate. For each 
medRxiv preprint doi: https://doi.org/10.1101/2021.05.04.21256508; this version posted May 7, 2021. The copyright holder for this preprint (which was not certified by peer review) is the author/funder, who has granted medRxiv a license to display the preprint in perpetuity.

It is made available under a CC-BY 4.0 International license .

SNP, regional plots are displayed at the age at peak association, highlighting the lead SNPs with red diamonds and SNPs coloured according to the $L D R^{2}$, with the exons of the gene according to Ensembl at the bottom and recombination rates in blue. 
medRxiv preprint doi: https://doi.org/10.1101/2021.05.04.21256508; this version posted May 7, 2021. The copyright holder for this preprint (which was not certified by peer review) is the author/funder, who has granted medRxiv a license to display the preprint in perpetuity.

It is made available under a CC-BY 4.0 International license .

A

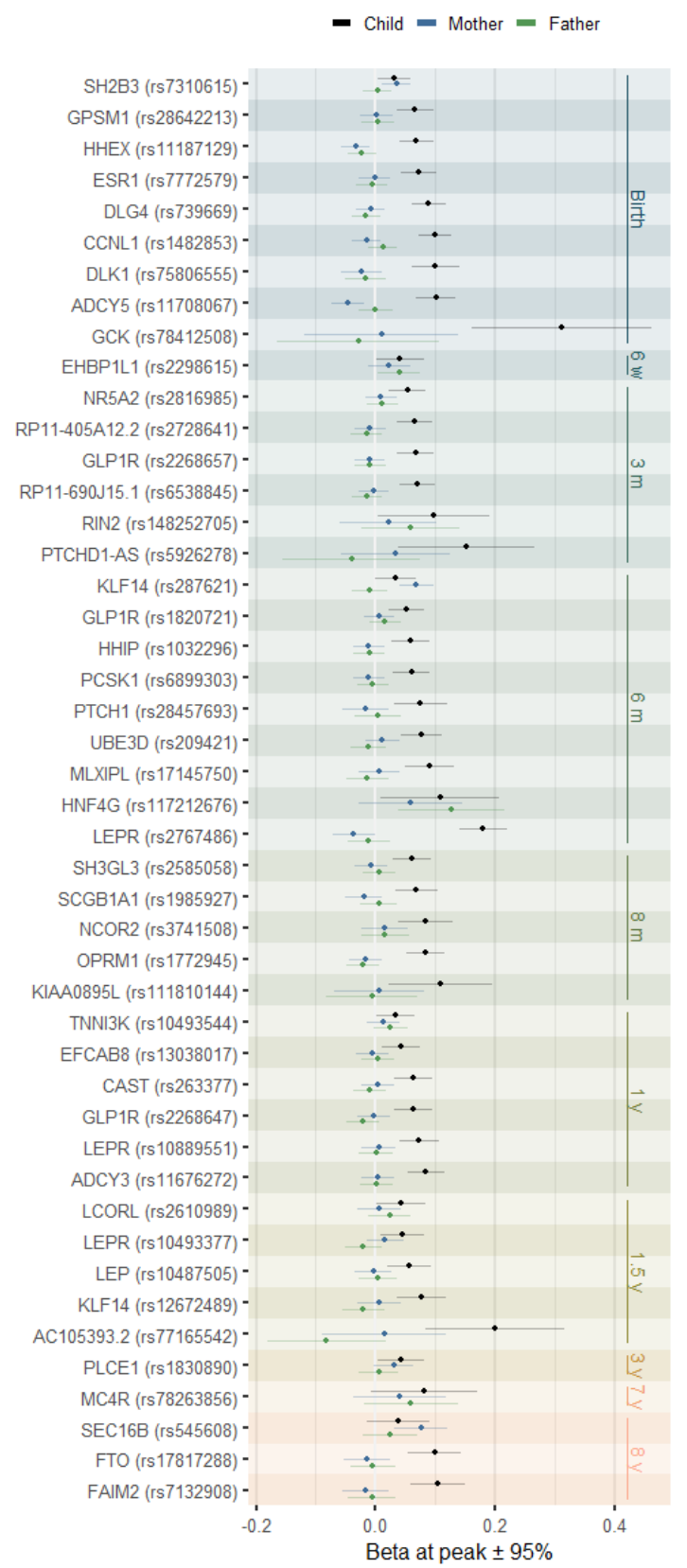

B
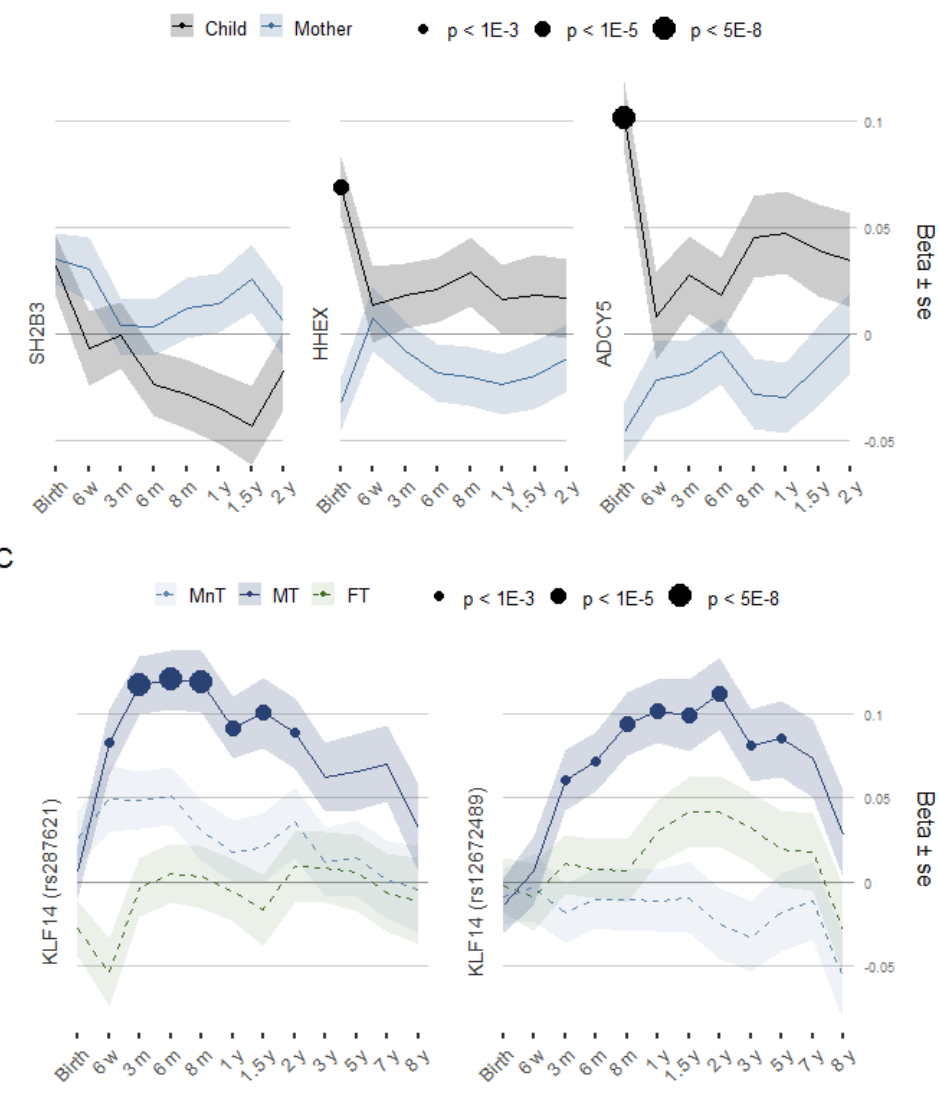

D

$\mathrm{R} 2 \cdot\left[\begin{array}{ll}0.0 & 0.2\end{array}\right] \cdot\left[\begin{array}{ll}0.2 & 0.4\end{array}\right] \cdot\left[\begin{array}{ll}0.4 & 0.6\end{array}\right]\left[\begin{array}{ll}0.6 & 0.8\end{array}\right] \bullet\left[\begin{array}{ll}0.8 & 1.0\end{array}\right]$
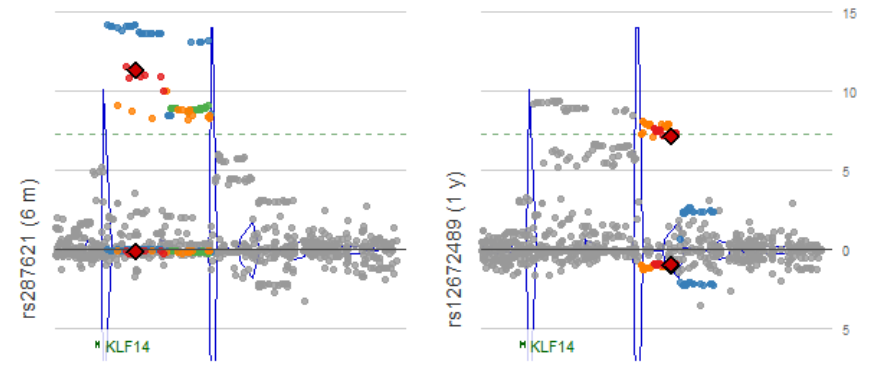

3
3
6
6
7
7
$\frac{7}{8}$
0
0
0
0
$\frac{0}{0}$
$\frac{0}{2}$
0
0

Figure 5 - Trio- and haplotype-resolved association profiles. (A) Effect size estimate for the conditional allelic association of the child, mother, and father with child standardized BMI for each of the 46 variants at age at peak association. The age at peak association is annotated to the right. Error bars represent $95 \%$ confidence intervals. Note that in this analysis child, mother, and father are conditioned on each other, see methods for details. (B) Association profile for birth weight loci known to present both maternal and fetal effect on birth weight. Effect size estimates of the association with child standardized $B M I$ are represented for the child and the mother from birth to two years of age (fathers were included in the model, but data are not displayed for the sake of readability). p-values represent the significance of the association with the number of effect alleles in the child, mother, and father in a joint model using unrelated trios, and thus differ from the $p$-values of the GWAS. Ribbons represent one standard error estimate on each side of the effect size estimate. (C) Association profiles with child standardized BMI 
medRxiv preprint doi: https://doi.org/10.1101/2021.05.04.21256508; this version posted May 7, 2021. The copyright holder for this preprint (which was not certified by peer review) is the author/funder, who has granted medRxiv a license to display the preprint in perpetuity. It is made available under a CC-BY 4.0 International license .

from birth to eight years of age for two variants upstream of KLF14 in a model combining the child, mother, and father alleles into four haplotypes: (MnT) allele non-transmitted from the mother to the child; (MT) allele transmitted from the mother to the child; (FT) allele transmitted from the father to the child; and (FnT) allele non-transmitted from the father to the child. Note that the FnT allele is not represented here for the sake of readability but results are available in Supplementary Table 4. p-values represent the significance of the association with the number of effect alleles for each haplotype in a joint model, and ribbons represent one standard error estimate on each side of the effect size estimate. (D) Regional plot for the $p$-values of association with the MT and FT haplotypes, top and bottom, respectively, in the haplotype-resolved model. The first and second locus, to the left and right, respectively, are annotated with a red diamond and SNPs coloured according to the $L D R^{2}$. The coordinates of the nearest exon coding for KLF14 according to Ensembl are annotated at the bottom. 
medRxiv preprint doi: https://doi.org/10.1101/2021.05.04.21256508; this version posted May 7, 2021. The copyright holder for this preprint (which was not certified by peer review) is the author/funder, who has granted medRxiv a license to display the preprint in perpetuity.

It is made available under a CC-BY 4.0 International license .

A

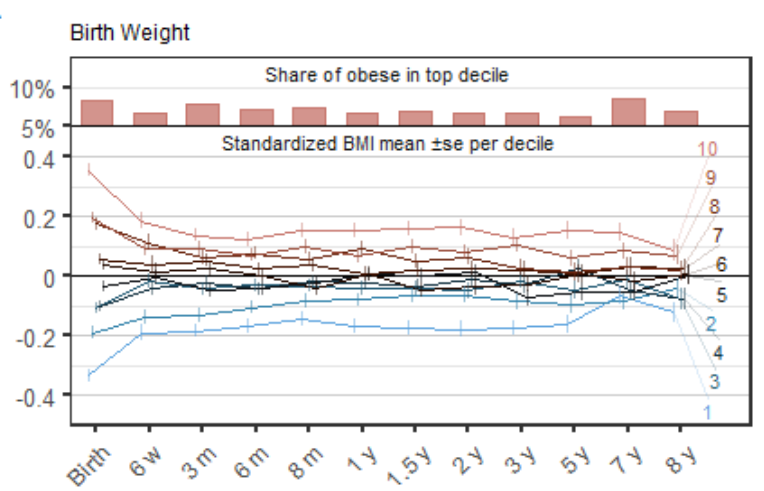

C

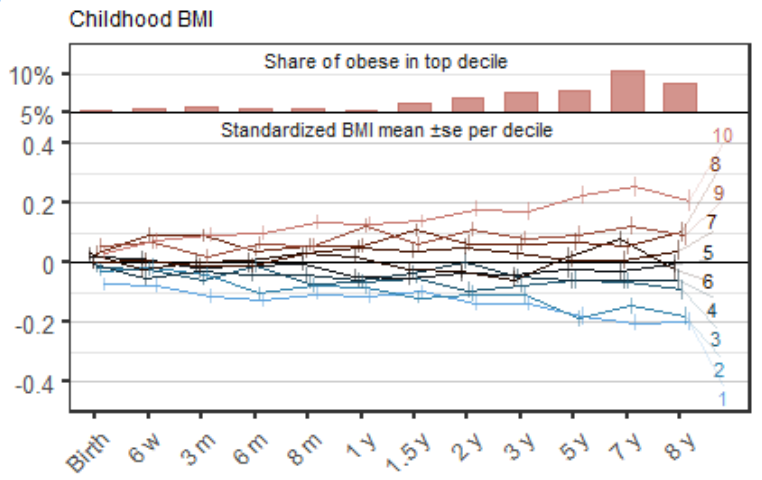

E

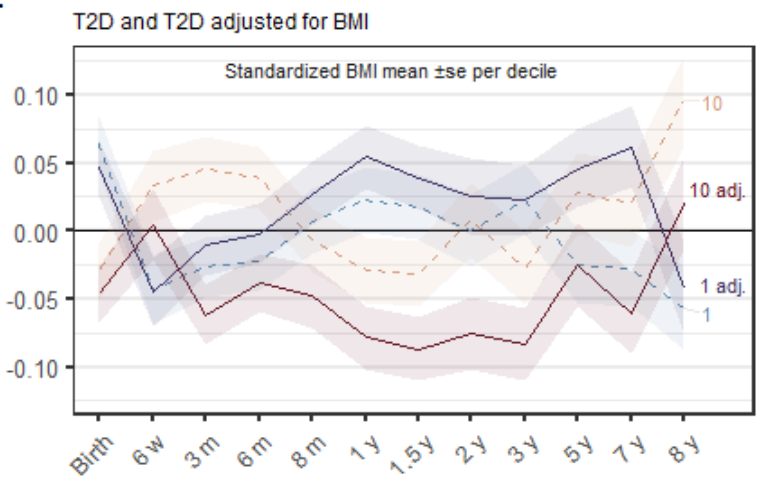

G

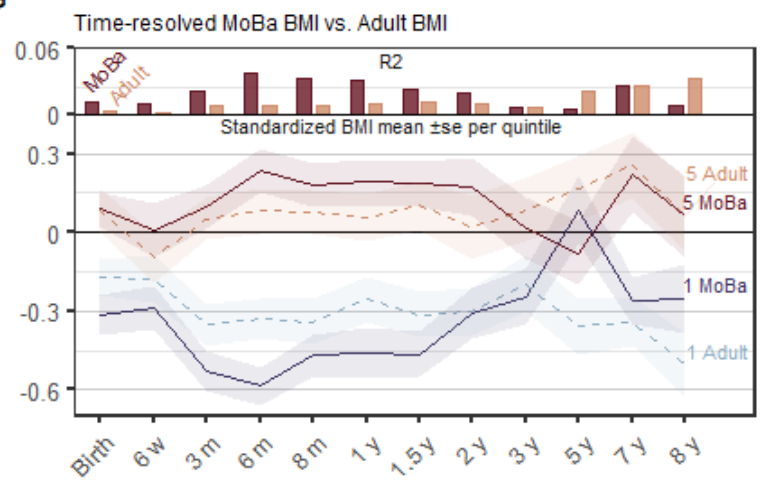

B

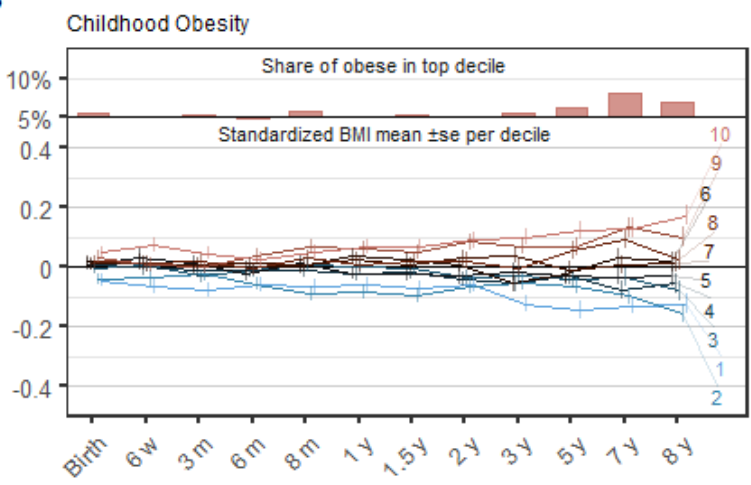

D

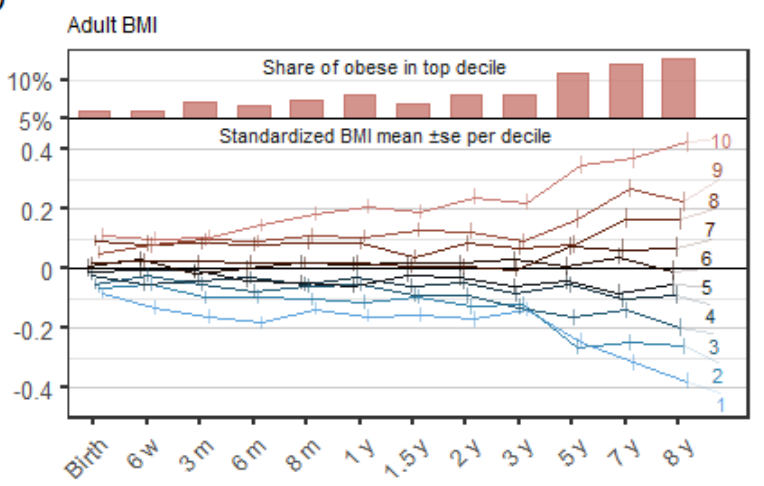

F

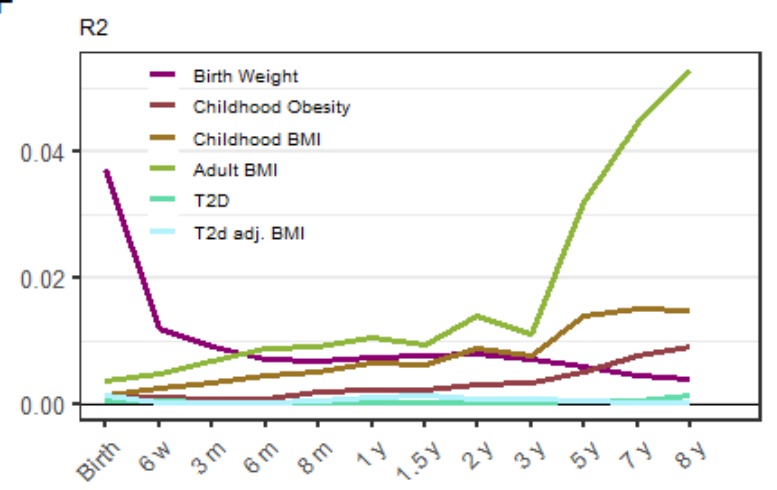

$\mathrm{H}$

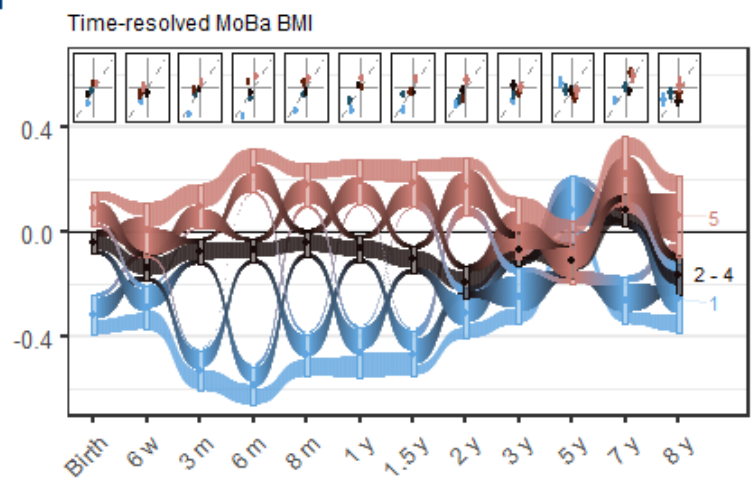

Figure 6 - Polygenic risk score (PRS) analyses. (A-D) Mean standardized BMI of children in this study 
medRxiv preprint doi: https://doi.org/10.1101/2021.05.04.21256508; this version posted May 7, 2021. The copyright holder for this preprint (which was not certified by peer review) is the author/funder, who has granted medRxiv a license to display the preprint in perpetuity.

It is made available under a CC-BY 4.0 International license .

at each time point after stratification in PRS deciles using PRS trained using summary statistics from meta-analyses (bottom), and share of obese children at a given time point in the top PRS decile (top), where obesity is defined as belonging to the top $5 \mathrm{BMI}$ percentile. PRS training was performed using summary statistics for $(A)$ birth weight from Warrington et al. ${ }^{24}(B)$ childhood obesity from Bradfield et al. ${ }^{16}$. (C) childhood BMI from Felix et al. ${ }^{14}$. (D) adult BMI from Yengo et al. ${ }^{13}$. (E) Mean standardized BMI for the children in this study falling in the top and bottom deciles of type 2 Diabetes (T2D) risk scores at each time point. PRS for T2D and T2D adjusted for BMI, represented in dashed and solid lines, respectively, were trained using summary statistics from Mahajan et al. ${ }^{43}$. (F) $R^{2}$ estimated at each time point when training the PRS for Birth weight, childhood obesity, childhood BMI, adult BMI, and T2D in Figures $5 A-E$. (G) Mean standardized BMI of children in MoBa that were kept out of the discovery sample falling in the top and bottom quintiles of time-resolved early growth PRSs trained using summary statistics of this study at each time point (solid lines) and of the adult BMI PRS of Figure 1D (dashed line) (Bottom), along with the respective $R^{2}$ estimated when training the PRSs (Top). (H) Mean standardized BMI of children in MoBa that were kept out of the discovery sample falling in the bottom, intermediate, and top quintiles of time-resolved early growth PRSs trained using summary statistics of this study at each time point, in blue, black, and red, respectively. At each time point, rectangles represent one standard error estimate on each side of the mean estimate. Transitions between time points represent the share of children moving from one quintile category to the other. For each time point, mean BMI estimates for these children after stratification in quintiles are plotted for time-resolved early growth PRSs against the adult BMI PRS of Figure 1D in inserts. All error bars/ribbons represent one standard error estimate on each side of the mean estimate. 
medRxiv preprint doi: https://doi.org/10.1101/2021.05.04.21256508; this version posted May 7, 2021. The copyright holder for this preprint (which was not certified by peer review) is the author/funder, who has granted medRxiv a license to display the preprint in perpetuity.

It is made available under a CC-BY 4.0 International license.

\section{Tables}


medRxiv preprint doi: https://doi.org/10.1101/2021.05.04.21256508; this version posted May 7, 2021. The copyright holder for this preprint (which was not certified by peer review) is the author/funder, who has granted medRxiv a license to display the preprint in perpetuity.

It is made available under a CC-BY 4.0 International license.

\begin{tabular}{|c|c|c|c|c|c|c|c|c|c|c|c|}
\hline Name & SNP & Chr & Position & $E A$ & $O A$ & $E A F$ & Age & Beta & $S E$ & P-value & Cluster \\
\hline$L E P R$ & rs10493377 & 1 & $65,879,252$ & A & G & $53 \%$ & $1.5 \mathrm{y}$ & 0.057 & 0.010 & 2.20E-09* & Transient \\
\hline LEPR & rs10889551 & 1 & $65,906,137$ & G & $A$ & $65 \%$ & $1 \mathrm{y}$ & 0.088 & 0.010 & $5.20 \mathrm{E}-19^{\star}$ & Transient \\
\hline$L E P R$ & rs2767486 & 1 & $65,991,203$ & G & $A$ & $16 \%$ & $6 \mathrm{~m}$ & 0.143 & 0.012 & $6.40 \mathrm{E}-34^{\star}$ & Transient \\
\hline TNNI3K & rs $10493544^{\mathrm{aBMI}}$ & 1 & $74,983,835$ & $\mathrm{~T}$ & $C$ & $43 \%$ & $8 \mathrm{~m}$ & 0.054 & 0.009 & $1.40 \mathrm{E}-08$ & Early Rise \\
\hline SEC16B & rs545608 & 1 & $177,899,121$ & C & $\mathrm{G}$ & $23 \%$ & $8 y$ & 0.088 & 0.016 & $3.20 \mathrm{E}-08$ & Late Rise \\
\hline NR5A2 & rs2816985 & 1 & $200,072,966$ & G & $A$ & $45 \%$ & $3 \mathrm{~m}$ & 0.059 & 0.009 & $5.40 \mathrm{E}-11$ & Transient \\
\hline AC105393.2 & rs77165542 & 2 & 430,975 & C & $\mathrm{T}$ & $98 \%$ & $1.5 \mathrm{y}$ & 0.187 & 0.032 & $3.50 \mathrm{E}-09$ & Early Rise \\
\hline$A D C Y 3$ & rs $11676272^{\mathrm{aBMI}}$ & 2 & $25,141,538$ & G & $A$ & $49 \%$ & $1 \mathrm{y}$ & 0.089 & 0.009 & $2.80 \mathrm{E}-22$ & Early Rise \\
\hline$A D C Y 5$ & rs $11708067^{\mathrm{BW}}$ & 3 & $123,065,778$ & G & $A$ & $23 \%$ & Birth & 0.079 & 0.010 & $5.20 \mathrm{E}-16$ & Birth \\
\hline CCNL1 & rs $1482853^{\mathrm{BW}}$ & 3 & $156,798,473$ & C & $A$ & $60 \%$ & Birth & 0.099 & 0.008 & $5.90 \mathrm{E}-32$ & Birth \\
\hline LCORL & rs2610989BW & 4 & $18,022,834$ & $\mathrm{~T}$ & $C$ & $26 \%$ & $1.5 \mathrm{y}$ & 0.060 & 0.011 & $5.50 \mathrm{E}-08^{\star}$ & Early Rise \\
\hline HHIP & rs1032296 & 4 & $145,434,688$ & $\mathrm{~T}$ & $C$ & $38 \%$ & $6 \mathrm{~m}$ & 0.052 & 0.009 & $1.10 \mathrm{E}-08$ & Transient \\
\hline PCSK1 & rs6899303 & 5 & $95,650,975$ & C & $A$ & $63 \%$ & $6 \mathrm{~m}$ & 0.057 & 0.009 & $5.30 \mathrm{E}-11^{*}$ & Transient \\
\hline PCSK1/CAST & rs263377 & 5 & $95,884,775$ & A & G & $41 \%$ & $1 \mathrm{y}$ & 0.054 & 0.010 & $2.90 \mathrm{E}-08^{*}$ & Transient \\
\hline GLP1R & rs2268657 & 6 & $39,020,542$ & $\mathrm{~T}$ & $C$ & $51 \%$ & $3 \mathrm{~m}$ & 0.056 & 0.009 & 8.40E-10* & Transient \\
\hline GLP1R & rs2268647 & 6 & $39,043,178$ & $\mathrm{~T}$ & $C$ & $50 \%$ & $1 \mathrm{y}$ & 0.048 & 0.009 & $2.60 \mathrm{E}-07^{\star}$ & Transient \\
\hline GLP1R & rs1820721 & 6 & $39,110,046$ & A & $C$ & $49 \%$ & $6 \mathrm{~m}$ & 0.061 & 0.009 & $7.20 \mathrm{E}-12^{\star}$ & Transient \\
\hline UBE3D & rs209421 & 6 & $83,523,684$ & G & $\mathrm{T}$ & $26 \%$ & $6 \mathrm{~m}$ & 0.073 & 0.010 & $5.40 \mathrm{E}-13$ & Transient \\
\hline ESR1 & rs7772579BW & 6 & $152,042,502$ & $A$ & $C$ & $70 \%$ & Birth & 0.065 & 0.009 & $5.90 \mathrm{E}-13$ & Birth \\
\hline OPRM1 & rs1772945 & 6 & $154,312,285$ & $A$ & $G$ & $56 \%$ & $8 \mathrm{~m}$ & 0.056 & 0.009 & $3.20 \mathrm{E}-09$ & Transient \\
\hline GCK & rs78412508 & 7 & $44,223,858$ & G & $A$ & $99 \%$ & Birth & 0.376 & 0.047 & $4.00 \mathrm{E}-15$ & Birth \\
\hline$M L X I P L$ & rs17145750 & 7 & $73,026,378$ & C & $\mathrm{T}$ & $84 \%$ & $6 \mathrm{~m}$ & 0.070 & 0.012 & $6.80 \mathrm{E}-09$ & Transient \\
\hline LEP & rs10487505 & 7 & $127,860,163$ & C & $\mathrm{G}$ & $49 \%$ & $1.5 \mathrm{y}$ & 0.056 & 0.009 & $3.20 \mathrm{E}-09$ & Early Rise \\
\hline$K L F 14$ & rs287621 & 7 & $130,435,181$ & $\mathrm{~T}$ & $C$ & $26 \%$ & $6 \mathrm{~m}$ & 0.064 & 0.010 & $3.70 \mathrm{E}-10^{*}$ & Transient \\
\hline$K L F 14$ & rs12672489 & 7 & $130,483,555$ & C & $\mathrm{T}$ & $75 \%$ & $1.5 \mathrm{y}$ & 0.067 & 0.011 & 2.10E-09* & Early Rise \\
\hline HNF4G & rs117212676 & 8 & $76,632,003$ & A & $\mathrm{G}$ & $2 \%$ & $6 \mathrm{~m}$ & 0.166 & 0.030 & $1.80 \mathrm{E}-07^{\star}$ & Early Rise \\
\hline PTCH1 & rs28457693 ${ }^{\mathrm{BW}}$ & 9 & $98,217,348$ & G & $A$ & $13 \%$ & $6 \mathrm{~m}$ & 0.073 & 0.013 & $2.40 \mathrm{E}-08$ & Transient \\
\hline GPSM1 & rs28642213 & 9 & $139,248,082$ & A & $\mathrm{G}$ & $27 \%$ & Birth & 0.062 & 0.010 & 4.70E-11 & Birth \\
\hline HHEX & rs11187129 & 10 & $94,429,907$ & C & $T$ & $46 \%$ & Birth & 0.047 & 0.008 & $2.10 \mathrm{E}-08$ & Birth \\
\hline PLCE1 & rs1830890 & 10 & $96,019,501$ & G & $A$ & $32 \%$ & $3 y$ & 0.067 & 0.012 & $1.30 \mathrm{E}-08$ & Early Rise \\
\hline$S C G B 1 A 1$ & rs1985927 & 11 & $62,193,537$ & C & $\mathrm{T}$ & $73 \%$ & $8 \mathrm{~m}$ & 0.060 & 0.011 & $6.80 \mathrm{E}-09$ & Early Rise \\
\hline EHBP1L1 & rs2298615 & 11 & $65,352,062$ & $\mathrm{~T}$ & $C$ & $23 \%$ & $6 w$ & 0.071 & 0.012 & 5.40E-09 & Transient \\
\hline
\end{tabular}


medRxiv preprint doi: https://doi.org/10.1101/2021.05.04.21256508; this version posted May 7, 2021. The copyright holder for this preprint (which was not certified by peer review) is the author/funder, who has granted medRxiv a license to display the preprint in perpetuity.

It is made available under a CC-BY 4.0 International license .

\begin{tabular}{|c|c|c|c|c|c|c|c|c|c|c|c|}
\hline$R P 11-405 A 12.2$ & rs2728641 & 12 & $20,111,569$ & $\mathrm{C}$ & $T$ & $48 \%$ & $3 \mathrm{~m}$ & 0.050 & 0.009 & $1.90 \mathrm{E}-08$ & Transient \\
\hline FAIM2 & rs7132908aBMl & 12 & $50,263,148$ & $A$ & $G$ & $40 \%$ & $8 y$ & 0.081 & 0.014 & $3.30 \mathrm{E}-09$ & Late Rise \\
\hline RP11-690J15.1 & rs6538845 & 12 & $98,544,888$ & C & $\mathrm{T}$ & $48 \%$ & $3 \mathrm{~m}$ & 0.055 & 0.009 & $1.50 \mathrm{E}-09$ & Early Rise \\
\hline SH2B3 & rs7310615 & 12 & $111,865,049$ & $G$ & C & $0.55 \%$ & Birth & 0.050 & 0.009 & $6.50 \mathrm{E}-09$ & Birth \\
\hline NCOR2 & rs3741508 & 12 & $124,812,678$ & $\mathrm{~T}$ & $\mathrm{G}$ & $86 \%$ & $8 \mathrm{~m}$ & 0.083 & 0.013 & $1.20 \mathrm{E}-09$ & Transient \\
\hline DLK1 & rs75806555 & 14 & $101,189,448$ & C & $\mathrm{T}$ & $86 \%$ & Birth & 0.074 & 0.012 & $2.10 \mathrm{E}-09$ & Birth \\
\hline SH3GL3 & rs2585058 & 15 & $84,284,552$ & $\mathrm{G}$ & $A$ & $53 \%$ & $8 \mathrm{~m}$ & 0.063 & 0.009 & $8.60 \mathrm{E}-12$ & Transient \\
\hline FTO & rs17817288aBMI & 16 & $53,807,764$ & $G$ & $A$ & $49 \%$ & $8 y$ & 0.095 & 0.013 & $1.30 \mathrm{E}-12$ & Late Rise \\
\hline KIAA0895L & rs111810144 & 16 & $67,216,110$ & $\mathrm{~T}$ & $\mathrm{C}$ & $3 \%$ & $8 \mathrm{~m}$ & 0.147 & 0.025 & $5.20 \mathrm{E}-09$ & Early Rise \\
\hline$D L G 4$ & rs739669 & 17 & $7,122,377$ & $A$ & $\mathrm{G}$ & $62 \%$ & Birth & 0.072 & 0.009 & $4.70 \mathrm{E}-17$ & Birth \\
\hline$M C 4 R$ & rs78263856 & 18 & $58,042,821$ & $\mathrm{~T}$ & $C$ & $95 \%$ & $7 y$ & 0.150 & 0.027 & $3.80 \mathrm{E}-08$ & Late Rise \\
\hline RIN2 & rs148252705 & 20 & $17,851,179$ & $\mathrm{~T}$ & C & $97 \%$ & $3 \mathrm{~m}$ & 0.157 & 0.029 & $2.60 \mathrm{E}-08$ & Transient \\
\hline EFCAB8 & rs13038017 & 20 & $31,467,551$ & $\mathrm{C}$ & $\mathrm{T}$ & $53 \%$ & $1 \mathrm{y}$ & 0.054 & 0.009 & $1.20 \mathrm{E}-08$ & Early Rise \\
\hline PTCHD1-AS & rs5926278 & $x$ & $23,296,291$ & $\mathrm{~T}$ & $C$ & $2 \%$ & $3 \mathrm{~m}$ & 0.149 & 0.027 & $4.80 \mathrm{E}-08$ & Transient \\
\hline
\end{tabular}

Table 1 - Association summary statistics for the top hits. Loci are ordered according to chromosomal position. SNP: rsid of the SNP with lowest p-value at age at peak association. Chr, Position: chromosome and position of the SNP in GRCh37 coordinates. EA, OA, EAF: effect allele, other allele, and effect allele frequency estimate in $\mathrm{MoBa}$, where the effect allele is the BMI-raising allele at age of peak association. Age: age at peak association defined as age with lowest association p-value. Name: locus name based on the nearest gene or previous naming in the literature. Beta, SE, P-value: effect size, standard error, and $p$-value estimates for the association with standardized BMI at age at peak. Cluster: Cluster corresponding to the effect size profile over time. Membership to multiple signals loci, and previous association of the lead SNP with birth weight (BW) in Warrington et al. ${ }^{24}$, adult BMI (aBMI) in Yengo et al. ${ }^{13}$, or both are annotated with superscripts. 


\section{Supplementary Figures}

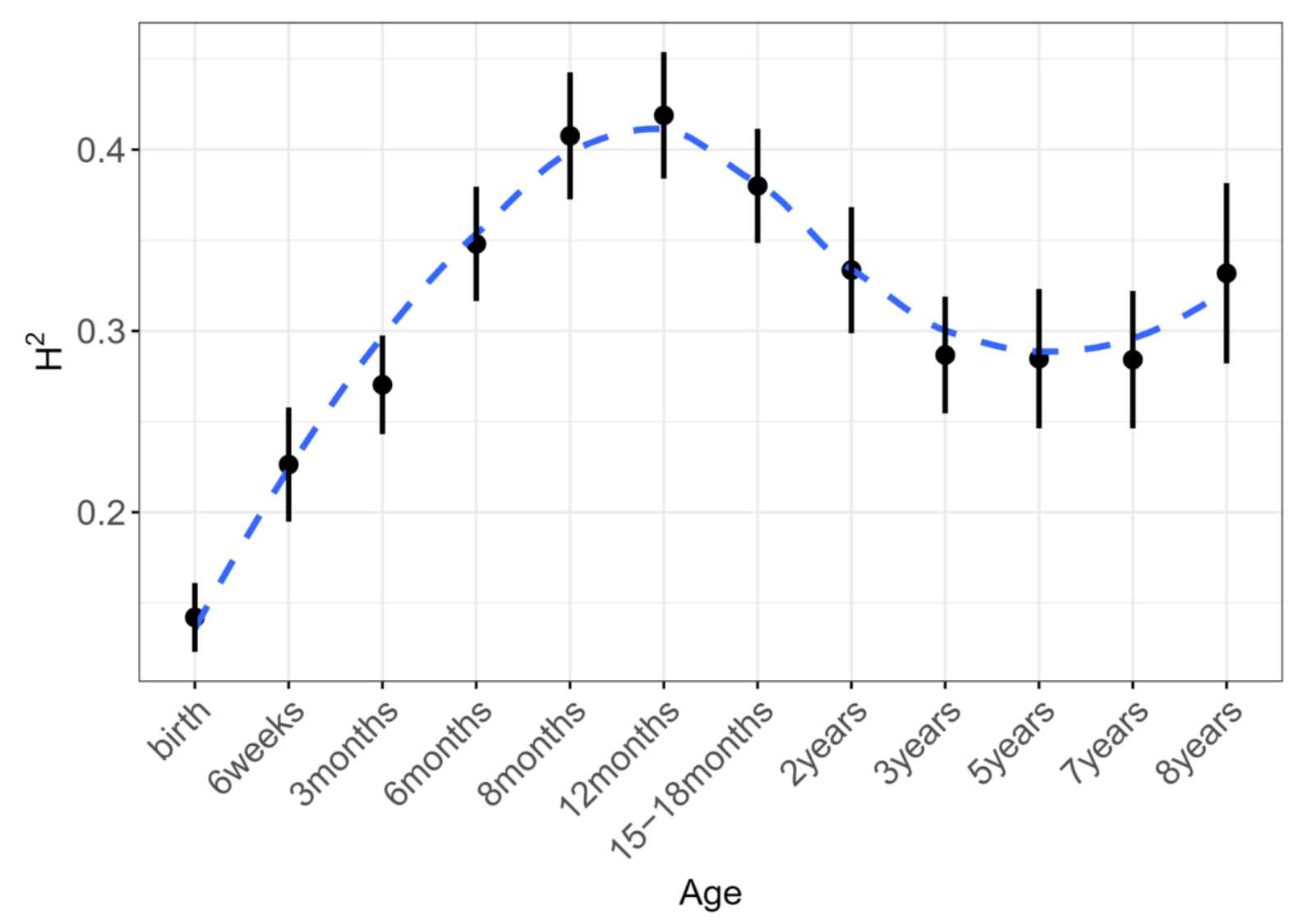

Supplementary Figure 1 - SNP-based heritability. $H^{2}$ estimates from LD score regression for BMI plotted at each time point (black) along with locally estimated scatterplot smoothing (LOESS) local regression (in blue). Error bars represent $\pm S E M$. 
medRxiv preprint doi: https://doi.org/10.1101/2021.05.04.21256508; this version posted May 7, 2021. The copyright holder for this preprint (which was not certified by peer review) is the author/funder, who has granted medRxiv a license to display the preprint in perpetuity.

It is made available under a CC-BY 4.0 International license .

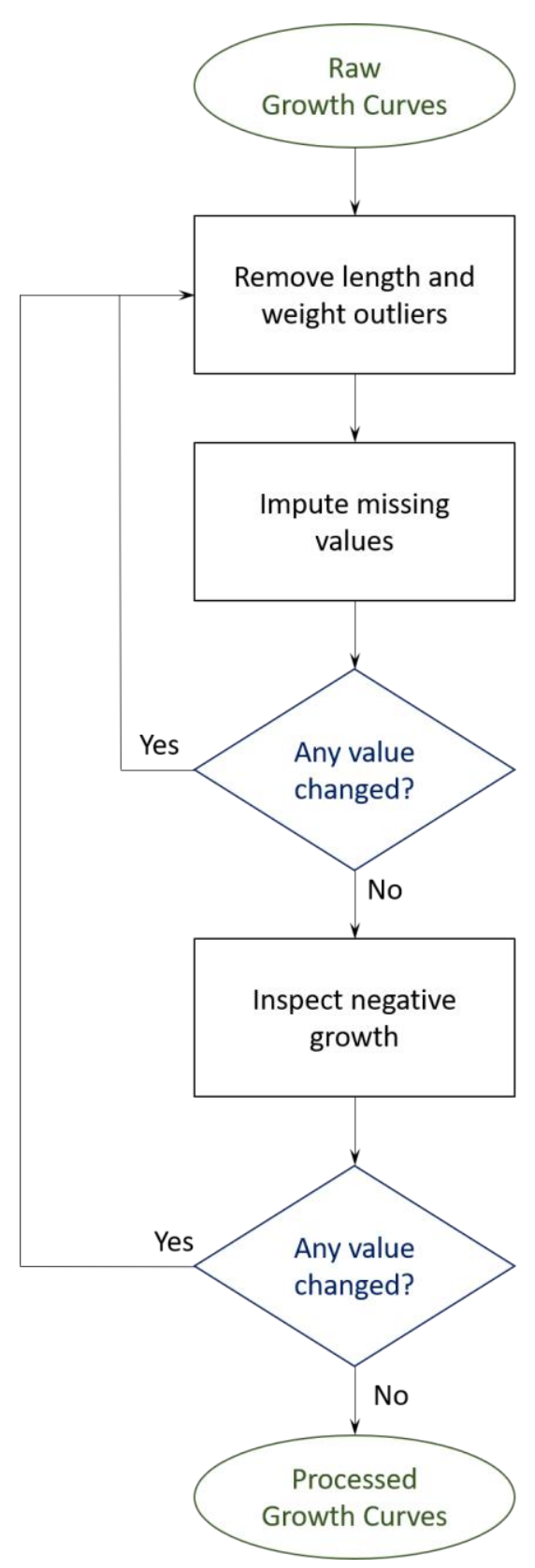

Supplementary Figure 2 - Growth curves processing. Length and Weight curves were inspected for outliers and missing values were imputed. This process was repeated until no value was changed. Then length values were inspected for negative growth and adjusted. The entire process was repeated until no value was changed. 
medRxiv preprint doi: https://doi.org/10.1101/2021.05.04.21256508; this version posted May 7, 2021. The copyright holder for this preprint

(which was not certified by peer review) is the author/funder, who has granted medRxiv a license to display the preprint in perpetuity.

It is made available under a CC-BY 4.0 International license.

\section{References}

1. Singh, A. S., Mulder, C., Twisk, J. W. R., van Mechelen, W. \& Chinapaw, M. J. M. Tracking of childhood overweight into adulthood: a systematic review of the literature. Obes. Rev. 9, 474-488 (2008).

2. NCD Risk Factor Collaboration (NCD-RisC). Worldwide trends in body-mass index, underweight, overweight, and obesity from 1975 to 2016: a pooled analysis of 2416 population-based measurement studies in 128.9 million children, adolescents, and adults. Lancet 390, 2627-2642 (2017).

3. Organization, W. H. \& Others. Consideration of the evidence on childhood obesity for the Commission on Ending Childhood Obesity: report of the ad hoc working group on science and evidence for ending childhood obesity, Geneva, Switzerland. (2016).

4. Woo, J. G. et al. Prediction of adult class II/III obesity from childhood BMI: the i3C consortium. Int. J. Obes. 44, 1164-1172 (2020).

5. Geserick, M. et al. Acceleration of BMI in Early Childhood and Risk of Sustained Obesity. N. Engl. J. Med. 379, 1303-1312 (2018).

6. MacLean, P. S., Higgins, J. A., Giles, E. D., Sherk, V. D. \& Jackman, M. R. The role for adipose tissue in weight regain after weight loss. Obes. Rev. 16 Suppl 1, 45-54 (2015).

7. Silventoinen, K. et al. Genetic and environmental effects on body mass index from infancy to the onset of adulthood: an individual-based pooled analysis of 45 twin cohorts participating in the COllaborative project of Development of Anthropometrical measures in Twins (CODATwins) study. Am. J. Clin. Nutr. 104, 371-379 (2016).

8. Silventoinen, K. et al. Differences in genetic and environmental variation in adult BMI by sex, age, time period, and region: an individual-based pooled analysis of 40 twin cohorts. Am. J. Clin. Nutr. 106, 457-466 (2017).

9. Kilpeläinen, T. O. et al. Physical activity attenuates the influence of FTO variants on obesity risk: a meta-analysis of 218,166 adults and 19,268 children. PLoS Med. 8, e1001116 (2011).

10. Khera, A. V. et al. Polygenic Prediction of Weight and Obesity Trajectories from Birth to Adulthood. Cell 177, 587-596.e9 (2019).

11. Yang, J. et al. Genetic variance estimation with imputed variants finds negligible missing heritability for human height and body mass index. Nature Genetics vol. 47 1114-1120 (2015).

12. Yang, J. et al. Genome partitioning of genetic variation for complex traits using common SNPs. Nat. Genet. 43, 519-525 (2011).

13. Yengo, L. et al. Meta-analysis of genome-wide association studies for height and body mass index in 700000 individuals of European ancestry. Hum. Mol. Genet. 27, 36413649 (2018).

14. Felix, J. F. et al. Genome-wide association analysis identifies three new susceptibility loci for childhood body mass index. Hum. Mol. Genet. 25, 389-403 (2016).

15. Vogelezang, S. et al. Novel loci for childhood body mass index and shared heritability with 
medRxiv preprint doi: https://doi.org/10.1101/2021.05.04.21256508; this version posted May 7, 2021. The copyright holder for this preprint (which was not certified by peer review) is the author/funder, who has granted medRxiv a license to display the preprint in perpetuity. It is made available under a CC-BY 4.0 International license.

adult cardiometabolic traits. PLoS Genet. 16, e1008718 (2020).

16. Bradfield, J. P. et al. A trans-ancestral meta-analysis of genome-wide association studies reveals loci associated with childhood obesity. Hum. Mol. Genet. 28, 3327-3338 (2019).

17. Helgeland, $\varnothing$. et al. Genome-wide association study reveals dynamic role of genetic variation in infant and early childhood growth. Nat. Commun. 10, 4448 (2019).

18. Alves, A. C. et al. GWAS on longitudinal growth traits reveals different genetic factors influencing infant, child, and adult BMI. Science Advances 5, eaaw3095 (2019).

19. Farooqi, I. S. et al. Effects of recombinant leptin therapy in a child with congenital leptin deficiency. N. Engl. J. Med. 341, 879-884 (1999).

20. Licinio, J. et al. Phenotypic effects of leptin replacement on morbid obesity, diabetes mellitus, hypogonadism, and behavior in leptin-deficient adults. Proc. Natl. Acad. Sci. U. S. A. 101, 4531-4536 (2004).

21. Marenne, G. et al. Exome Sequencing Identifies Genes and Gene Sets Contributing to Severe Childhood Obesity, Linking PHIP Variants to Repressed POMC Transcription. Cell Metab. 31, 1107-1119.e12 (2020).

22. Magnus, P. et al. Cohort Profile Update: The Norwegian Mother and Child Cohort Study (MoBa). Int. J. Epidemiol. 45, 382-388 (2016).

23. Yang, J. et al. Conditional and joint multiple-SNP analysis of GWAS summary statistics identifies additional variants influencing complex traits. Nat. Genet. 44, 369-75, S1-3 (2012).

24. Warrington, N. M. et al. Maternal and fetal genetic effects on birth weight and their relevance to cardio-metabolic risk factors. Nat. Genet. (2019) doi:10.1038/s41588-0190403-1.

25. Khan, S. et al. BBS5 and INPP5E mutations associated with ciliopathy disorders in families from Pakistan. Ann. Hum. Genet. 83, 477-482 (2019).

26. Hampshire, D. J. et al. MORM syndrome (mental retardation, truncal obesity, retinal dystrophy and micropenis), a new autosomal recessive disorder, links to 9q34. Eur. J. Hum. Genet. 14, 543-548 (2006).

27. Sun, Q. et al. Genome-wide association study identifies polymorphisms in LEPR as determinants of plasma soluble leptin receptor levels. Hum. Mol. Genet. 19, 1846-1855 (2010).

28. Saeed, S. et al. Loss-of-function mutations in ADCY3 cause monogenic severe obesity. Nat. Genet. 50, 175-179 (2018).

29. Stergiakouli, E. et al. Genome-wide association study of height-adjusted BMI in childhood identifies functional variant in ADCY3. Obesity 22, 2252-2259 (2014).

30. Krashes, M. J., Lowell, B. B. \& Garfield, A. S. Melanocortin-4 receptor-regulated energy homeostasis. Nat. Neurosci. 19, 206-219 (2016).

31. Jackson, R. S. et al. Obesity and impaired prohormone processing associated with mutations in the human prohormone convertase 1 gene. Nat. Genet. 16, 303-306 (1997).

32. Martín, M. G. et al. Congenital proprotein convertase 1/3 deficiency causes malabsorptive diarrhea and other endocrinopathies in a pediatric cohort. Gastroenterology 145, 138-148 (2013).

33. Ramos-Molina, B., Martin, M. G. \& Lindberg, I. PCSK1 Variants and Human Obesity. Prog. Mol. Biol. Transl. Sci. 140, 47-74 (2016). 
medRxiv preprint doi: https://doi.org/10.1101/2021.05.04.21256508; this version posted May 7, 2021. The copyright holder for this preprint (which was not certified by peer review) is the author/funder, who has granted medRxiv a license to display the preprint in perpetuity. It is made available under a CC-BY 4.0 International license .

34. Sun, B. B. et al. Genomic atlas of the human plasma proteome. Nature 558, 73-79 (2018).

35. Turcot, V. et al. Protein-altering variants associated with body mass index implicate pathways that control energy intake and expenditure in obesity. Nat. Genet. 50, 26-41 (2018).

36. Alvarez, E. et al. The expression of GLP-1 receptor mRNA and protein allows the effect of GLP-1 on glucose metabolism in the human hypothalamus and brainstem. J. Neurochem. 92, 798-806 (2005).

37. Yau, A. M. W. et al. A Pilot Study Investigating the Influence of Glucagon-Like Peptide-1 Receptor Single Nucleotide Polymorphisms on Gastric Emptying Rate in Caucasian Men. Frontiers in Physiology vol. 9 (2018).

38. Small, K. S. et al. Regulatory variants at KLF14 influence type 2 diabetes risk via a femalespecific effect on adipocyte size and body composition. Nat. Genet. 50, 572-580 (2018).

39. Kong, A. et al. Parental origin of sequence variants associated with complex diseases. Nature 462, 868-874 (2009).

40. Yang, Q. \& Civelek, M. Transcription Factor KLF14 and Metabolic Syndrome. Front Cardiovasc Med 7, 91 (2020).

41. Yaghootkar, H. et al. Genetic Studies of Leptin Concentrations Implicate Leptin in the Regulation of Early Adiposity. Diabetes (2020) doi:10.2337/db20-0070.

42. Choi, S. W. \& O'Reilly, P. F. PRSice-2: Polygenic Risk Score software for biobank-scale data. Gigascience 8, (2019).

43. Mahajan, A. et al. Fine-mapping type 2 diabetes loci to single-variant resolution using highdensity imputation and islet-specific epigenome maps. Nat. Genet. 50, 1505-1513 (2018).

44. Murray, P. G. \& Clayton, P. E. Endocrine control of growth. Am. J. Med. Genet. C Semin. Med. Genet. 163C, 76-85 (2013).

45. González-García, I., Milbank, E., Diéguez, C., López, M. \& Contreras, C. Glucagon, GLP-1 and Thermogenesis. Int. J. Mol. Sci. 20, (2019).

46. Kelly, A. S. et al. A Randomized, Controlled Trial of Liraglutide for Adolescents with Obesity. N. Engl. J. Med. 382, 2117-2128 (2020).

47. Farr, O. M. et al. GLP-1 receptors exist in the parietal cortex, hypothalamus and medulla of human brains and the GLP-1 analogue liraglutide alters brain activity related to highly desirable food cues in individuals with diabetes: a crossover, randomised, placebocontrolled trial. Diabetologia 59, 954-965 (2016).

48. Beiroa, D. et al. GLP-1 agonism stimulates brown adipose tissue thermogenesis and browning through hypothalamic AMPK. Diabetes 63, 3346-3358 (2014).

49. Vendrell, J. et al. Study of the potential association of adipose tissue GLP-1 receptor with obesity and insulin resistance. Endocrinology 152, 4072-4079 (2011).

50. Delaneau, O., Zagury, J.-F. \& Marchini, J. Improved whole-chromosome phasing for disease and population genetic studies. Nat. Methods 10, 5-6 (2013).

51. Durbin, R. Efficient haplotype matching and storage using the positional Burrows-Wheeler transform (PBWT). Bioinformatics 30, 1266-1272 (2014).

52. Loh, P.-R. et al. Efficient Bayesian mixed-model analysis increases association power in large cohorts. Nat. Genet. 47, 284-290 (2015).

53. 1000 Genomes Project Consortium et al. An integrated map of genetic variation from 1,092 human genomes. Nature 491, 56-65 (2012). 
medRxiv preprint doi: https://doi.org/10.1101/2021.05.04.21256508; this version posted May 7, 2021. The copyright holder for this preprint (which was not certified by peer review) is the author/funder, who has granted medRxiv a license to display the preprint in perpetuity.

It is made available under a CC-BY 4.0 International license.

54. McLaren, W. et al. The Ensembl Variant Effect Predictor. Genome Biol. 17, 122 (2016).

55. Jassal, B. et al. The reactome pathway knowledgebase. Nucleic Acids Res. 48, D498D503 (2020).

56. Sánchez, L. F. H. et al. PathwayMatcher: proteoform-centric network construction enables fine-granularity multiomics pathway mapping. Gigascience 8, (2019).

57. Staley, J. R. et al. PhenoScanner: a database of human genotype-phenotype associations. Bioinformatics 32, 3207-3209 (2016).

58. Kamat, M. A. et al. PhenoScanner V2: an expanded tool for searching human genotypephenotype associations. Bioinformatics 35, 4851-4853 (2019).

59. Chen, J. et al. Haplotype genetic score analysis in 10,734 mother/infant pairs reveals complex maternal and fetal genetic effects underlying the associations between maternal phenotypes, birth outcomes and adult phenotypes. Cold Spring Harbor Laboratory 737106 (2019) doi:10.1101/737106. 